\title{
Conjugation of Aminoadamantane and $\gamma$-Carboline Pharmacophores Gives Rise to Unexpected Properties of Multifunctional Ligands
}

\author{
Sergey O. Bachurin ${ }^{1, *} \mathbb{D}$, Galina F. Makhaeva ${ }^{1}\left(\mathbb{D}\right.$, Elena F. Shevtsova ${ }^{1}\left(\mathbb{D}\right.$, Alexey Yu. Aksinenko ${ }^{1}(\mathbb{D}$, \\ Vladimir V. Grigoriev ${ }^{1}{ }^{1}$, Pavel N. Shevtsov ${ }^{1}{ }^{1}$, Tatiana V. Goreva ${ }^{1}$, Tatiana A. Epishina ${ }^{1}$, \\ Nadezhda V. Kovaleva ${ }^{1}$, Elena A. Pushkareva ${ }^{1}{ }^{\mathbb{D}}$, Natalia P. Boltneva ${ }^{1} \mathbb{D}$, Sofya V. Lushchekina ${ }^{1,2} \mathbb{D}^{\mathbb{D}}$, \\ Alexey V. Gabrelyan ${ }^{1}$, Vladimir L. Zamoyski ${ }^{1}$, Lyudmila G. Dubova ${ }^{1}$, Elena V. Rudakova ${ }^{1}{ }^{1}$,

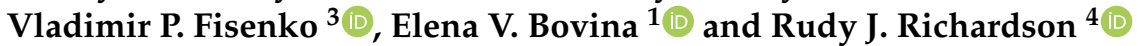

check for updates

Citation: Bachurin, S.O.

Makhaeva, G.F.; Shevtsova, E.F.; Aksinenko, A.Y.; Grigoriev, V.V.; Shevtsov, P.N.; Goreva, T.V.; Epishina, T.A.; Kovaleva, N.V.; Pushkareva, E.A.; et al. Conjugation of Aminoadamantane and $\gamma$-Carboline Pharmacophores Gives Rise to Unexpected Properties of Multifunctional Ligands. Molecules 2021, 26, 5527. https://doi.org/ $10.3390 /$ molecules 26185527

Academic Editor: Ludovic Jean

Received: 3 August 2021

Accepted: 9 September 2021

Published: 11 September 2021

Publisher's Note: MDPI stays neutral with regard to jurisdictional claims in published maps and institutional affiliations.

Copyright: (c) 2021 by the authors Licensee MDPI, Basel, Switzerland. This article is an open access article distributed under the terms and conditions of the Creative Commons Attribution (CC BY) license (https:// creativecommons.org/licenses/by/ $4.0 /)$
1 Institute of Physiologically Active Compounds, Russian Academy of Sciences, 142432 Chernogolovka, Russia; gmakh@ipac.ac.ru (G.F.M.); shevtsova@ipac.ac.ru (E.F.S.); alaks@ipac.ac.ru (A.Y.A.); grigor@ipac.ac.ru (V.V.G.); pnshevtsov@gmail.com (P.N.S.); tg1960@mail.ru (T.V.G.); tatiana.epishina@mail.ru (T.A.E.); kovalevanv@ipac.ac.ru (N.V.K.); l.kickeeva@yandex.ru (E.A.P.); boltneva@ipac.ac.ru (N.P.B.); sofya.lushchekina@gmail.com (S.V.L.); avg@ipac.ac.ru (A.V.G.); vzam@yandex.ru (V.L.Z.); dubova@ipac.ac.ru (L.G.D.); rudakova@ipac.ac.ru (E.V.R.); bovina_e@ipac.ac.ru (E.V.B.)

2 Emanuel Institute of Biochemical Physics, Russian Academy of Sciences, 119334 Moscow, Russia

3 I.M.Sechenov First Moscow State Medical University, 8 Build. 2 Trubetskaya Str., 119991 Moscow, Russia; vpfisenko@mail.ru

4 Department of Environmental Health Sciences, University of Michigan, Ann Arbor, MI 48109, USA; rjrich@umich.edu

* Correspondence: bachurin@ipac.ac.ru; Tel.: +7-(496)-524-2650

\begin{abstract}
A new series of conjugates of aminoadamantane and $\gamma$-carboline, which are basic scaffolds of the known neuroactive agents, memantine and dimebon (Latrepirdine) was synthesized and characterized. Conjugates act simultaneously on several biological structures and processes involved in the pathogenesis of Alzheimer's disease and some other neurodegenerative disorders. In particular, these compounds inhibit enzymes of the cholinesterase family, exhibiting higher inhibitory activity against butyrylcholinesterase (BChE), but having almost no effect on the activity of carboxylesterase (anti-target). The compounds serve as NMDA-subtype glutamate receptor ligands, show mitoprotective properties by preventing opening of the mitochondrial permeability transition (MPT) pore, and act as microtubule stabilizers, stimulating the polymerization of tubulin and microtubule-associated proteins. Structure-activity relationships were studied, with particular attention to the effect of the spacer on biological activity. The synthesized conjugates showed new properties compared to their prototypes (memantine and dimebon), including the ability to bind to the ifenprodil-binding site of the NMDA receptor and to occupy the peripheral anionic site of acetylcholinesterase (AChE), which indicates that these compounds can act as blockers of AChE-induced $\beta$-amyloid aggregation. These new attributes of the conjugates represent improvements to the pharmacological profiles of the separate components by conferring the potential to act as neuroprotectants and cognition enhancers with a multifunctional mode of action.
\end{abstract}

Keywords: multifunctional agents; Alzheimer's disease; cholinesterases; NMDA receptor; mitochondrial permeability transition (MPT) pore; microtubules

\section{Introduction}

Every year, nearly 10 million new patients are diagnosed with neurodegenerative diseases (NDs), such as Alzheimer's disease (AD) and other types of dementias [1,2]. As of 2019, over 2100 clinical trials were performed with various agents as treatments for 
$\mathrm{AD}$ [3]. However, there are only a few drugs recommended for treatment of $\mathrm{AD}$ and other NDs. Thus, only four low-molecular agents are extensively used in the therapy of AD (donepezil, rivastigmine, galantamine, memantine) and one monoclonal antibody agentaducanumab, which was approved in 2021. The former three drugs are cholinesterase inhibitors, whereas memantine is an NMDA-receptor channel blocker. It should be noted that all these drugs only provide some relief to the symptoms of AD. The fact that only a small number of drugs has been approved for the pharmacotherapy of $\mathrm{AD}$ and that these agents provide only partial amelioration of symptoms without altering the progression of the disease attests to the multifactorial nature of the disease and our incomplete understanding of its pathogenesis [4,5]. Therefore, the construction of multifunctional disease-modifying agents that can act simultaneously on several targets thought to be involved in the pathogenesis of the disease is a current trend in the design of new effective treatments of these pathologies [6,7].

Previously, we used approaches to the construction of several types of multifunctional ligands including those based on carbazole- $\gamma$-carboline, carbazole-aminoadamantane and $\gamma$-carboline-phenothiazine conjugates [8-13]. In the current work, we investigated approaches to the design of new binary compounds based on aminoadamantane and $\gamma$-carboline and characterized the synthesized compounds. These compounds can be considered as conjugates of the drug memantine, acting as a blocker of brain NMDA receptors $[14,15]$, and the drug dimebon. The latter showed strong neuroprotective properties in phase II clinical trials [16]; however, because of an abnormal placebo effect in phase III clinical trials, it was not further developed [17]. Meanwhile, subsequent studies of dimebon and its analogs provided convincing evidence that this compound has a significant mitoprotective effect, inhibits the development of proteinopathy and affects a number of enzyme and receptor systems (such as acetylcholinesterase (AChE) and butyrylcholinesterase (BChE), 5-HT7 and 5-HT6 subtype serotonin receptors, NMDA- and AMPA-subtype glutamate receptors and some others involved in neurotransmission) [18-22]. Therefore, a combination of active pharmacophores (aminoadamantane and $\gamma$-carboline in one chemical structure is of great interest. Our design of the conjugates is presented in Figure 1.
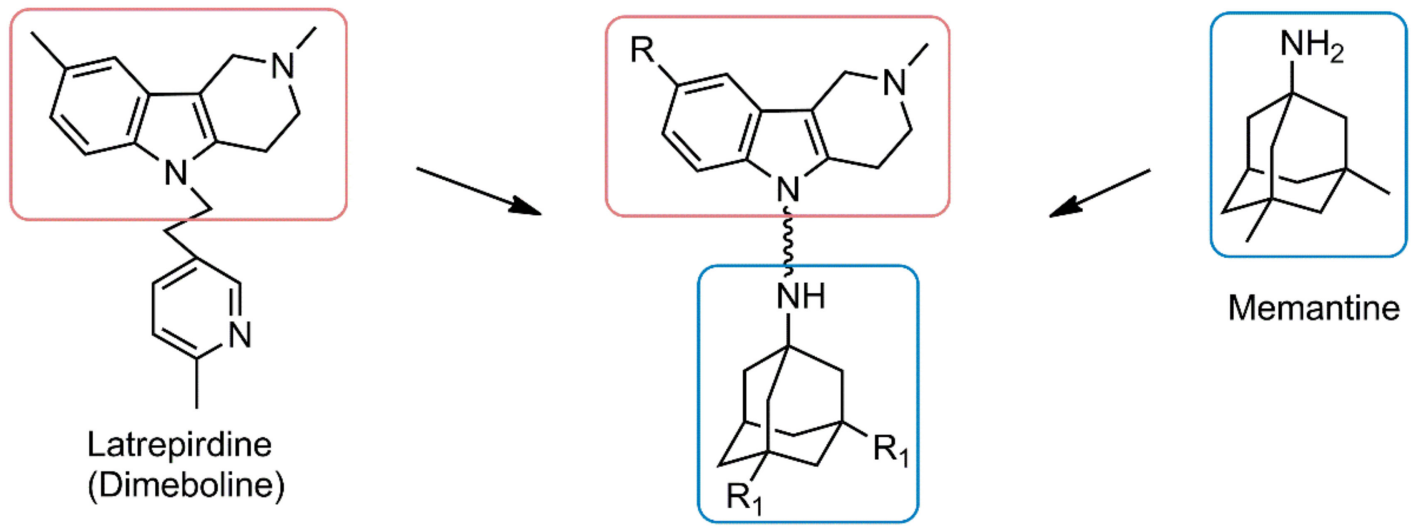<smiles>CCCCCCCC(C)=O</smiles>

$$
\mathrm{R}=\mathrm{H}, \mathrm{Me}, \mathrm{F} ; \quad \mathrm{R}_{1}=\mathrm{H}, \mathrm{Me}
$$

Figure 1. Design of aminoadamantane- $\gamma$-carboline conjugates.

We studied the interactions of the synthesized conjugates with the two binding sites of the NMDA receptor: the intrachannel (MK-801-binding) and peripheral (ifenprodilbinding) sites. We used enzyme kinetics and molecular docking to investigate interactions of the conjugates with enzymes of the cholinergic nervous system, acetylcholinesterase (EC 3.1.1.7, AChE) and butyrylcholinesterase (EC 3.1.1.8, BChE), and the structurally related 
enzyme carboxylesterase (EC 3.1.1.1, CES), the inhibition of which can lead to unwanted drug-drug interactions (anti-target). We also evaluated the ability of the new conjugates to bind to the peripheral anionic site (PAS) of AChE from Electrophorus electricus (EeAChE) and competitively displace its selective ligand propidium iodide as an indicator of their potential ability to prevent AChE-induced $\beta$-amyloid aggregation. In order to evaluate the potential toxicity and the neuroprotective effect of the compounds, we evaluated the action of the new aminoadamantane- $\gamma$-carboline conjugates on the mitochondrial potential and calcium-induced mitochondrial permeability transition (MPT) pore opening, respectively. The possibility to compensate microtubule destabilization upon tauopathy was assessed based on the ability of the new compounds to stimulate the polymerization of tubulin and microtubule-associated proteins.

\section{Results and Discussion}

\subsection{Chemistry}

The target compounds were synthesized as outlined in Schemes 1 and 2. A series of aminoadamantane- $\gamma$-carboline conjugates linked via an ethylene spacer was synthesized starting from methanesulfonates $\mathbf{1 a}-\mathbf{c}$. Methanesulfonates $\mathbf{1 a}-\mathbf{c}$ were prepared by the reactions of tetrahydro- $\gamma$-carbolines with ethane-1,2-diyl dimethanesulfonate in the presence of an equimolar amount of sodium hydride as described [23] and were then heated with 1aminoadamantanes $\mathbf{2 a} \mathbf{a} \mathbf{b}$ in sealed tubes for 3 days at $140^{\circ} \mathrm{C}$. Conjugates $\mathbf{3 a}-\mathbf{f}$ were isolated by column chromatography and converted into corresponding hydrochlorides $\mathbf{4 a}-\mathbf{f}$.

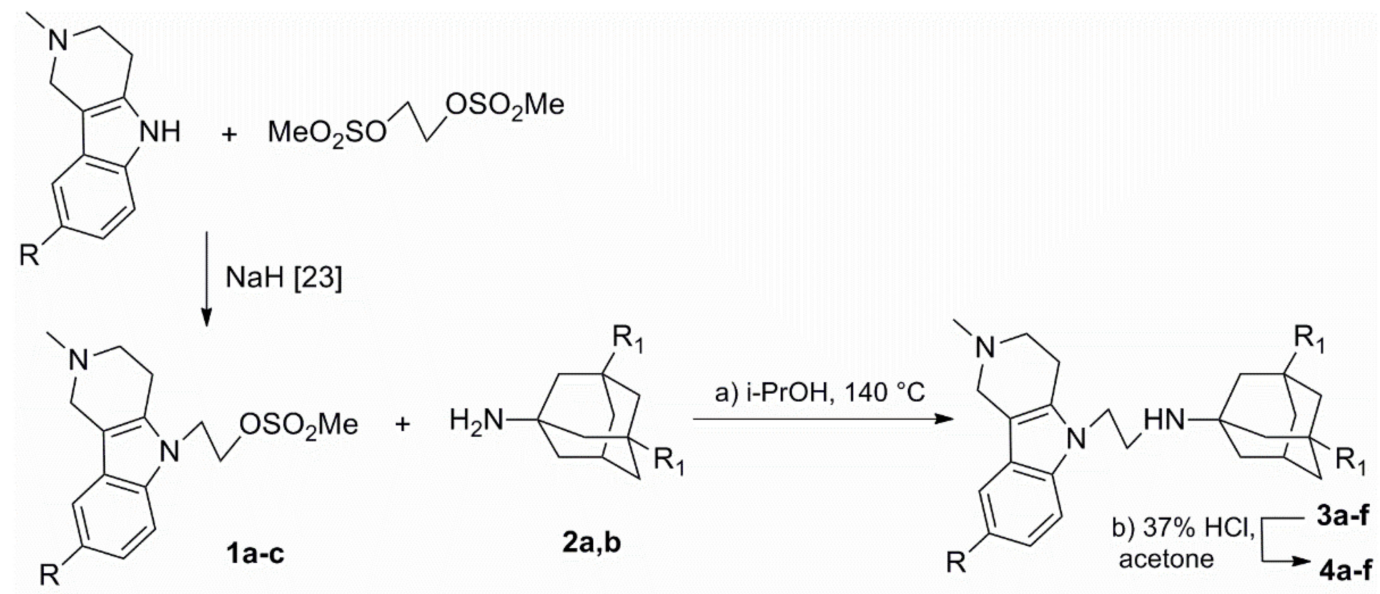

Scheme 1. Synthesis of compounds $4 a-f$. Reagents and conditions: (a) i-PrOH, $140{ }^{\circ} \mathrm{C}$, sealed tube, 3 days, (b) $37 \%(v / v)$ $\mathrm{HCl}$, acetone.
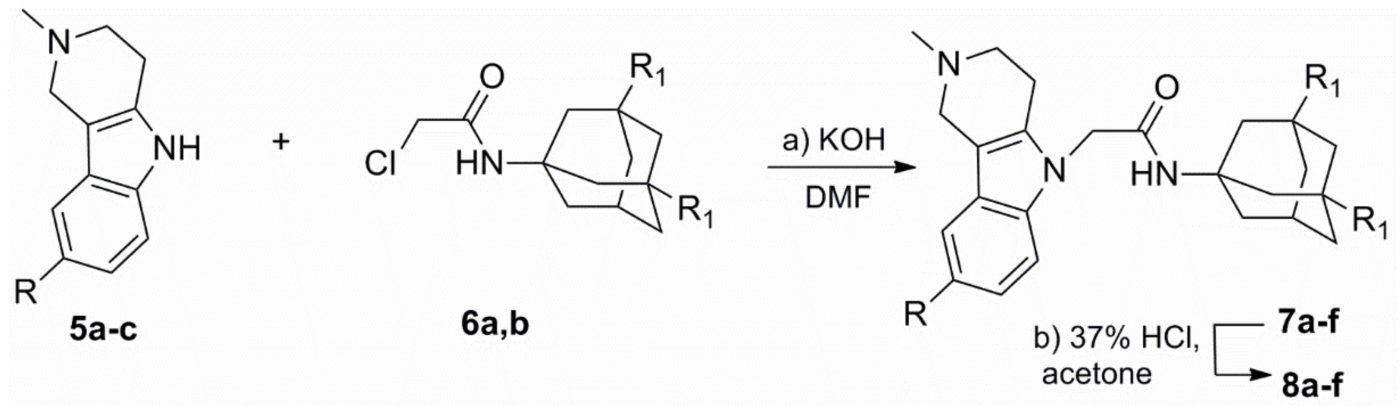

Scheme 2. Synthesis of compounds 8a-f. Reagents and conditions: (a) $\mathrm{KOH}, 20^{\circ} \mathrm{C}, 3 \mathrm{~h},(\mathbf{b}) 37 \%(v / v) \mathrm{HCl}$, acetone.

A series of aminoadamantane- $\gamma$-carboline conjugates linked via an oxoethylene spacer was synthesized by the reaction of chloroacetylaminoadamantanes with $\gamma$-carbolines. $\gamma$-Carbolines 1a-c were alkylated with $N$-(adamantan-1-yl)chloroacetamides $\mathbf{6 a}, \mathbf{b}$ in the 
presence of $\mathrm{KOH}$ to give conjugates $\mathbf{7 a}-\mathbf{f}$ in high yields, and the latter compounds were transformed into corresponding hydrochlorides $\mathbf{8 a}-\mathbf{f}$. All the synthesized compounds were characterized by ${ }^{1} \mathrm{H},{ }^{13} \mathrm{C}$ and ${ }^{19} \mathrm{~F}$ NMR spectroscopy and elemental analysis.

The IR spectra showed the characteristic appearance of an absorption band in the 3450-3400 (NH), 2910-2900 $\left(\mathrm{CH}_{2}\right), 2854-2840\left(\mathrm{NCH}_{3}\right), 1679-1675(\mathrm{C}=\mathrm{O}), 1545-1542(\mathrm{NH}$ of amide) and 1464-1452 (CH of $\left.\mathrm{CH}_{2}\right) \mathrm{cm}^{-1}$ range. ${ }^{1} \mathrm{H}$ and ${ }^{13} \mathrm{C}$ NMR spectra represent a superposition of the signals of the tetrahydro- $\gamma$-carboline ring, aminoadamantane fragment and ethylene or oxoethylene spacers. Characteristic signals of two spacers in ${ }^{1} \mathrm{H}$ NMR spectra appear in the ranges of 4.3-4.7 ppm for the $\mathrm{NCH}_{2} \mathrm{CH}_{2} \mathrm{NH}$ spacer of compounds $4 \mathbf{a}-\mathbf{f}$ and in the ranges of $4.68-4.76 \mathrm{ppm}$ for the $\mathrm{NCH}_{2} \mathrm{C}(\mathrm{O})$ spacer of compounds $8 \mathbf{a}-\mathbf{f}$. Signals of ${ }^{13} \mathrm{C}$ NMR spectra in the ranges of 56-58 ppm were assigned to methylene of the $\mathrm{NCH}_{2} \mathrm{CH}_{2} \mathrm{NH}$ spacer of compounds $4 \mathbf{a}-\mathbf{f}$, while the $\mathrm{NCH}_{2} \mathrm{C}(\mathrm{O})$ spacer of compounds $8 \mathbf{a}-\mathbf{f}$ demonstrate signals of methylene protons at $46 \mathrm{ppm}$ and $166 \mathrm{ppm}$ of the carbonyl group.

\subsection{Effect of Aminoadamantane- $\gamma$-Carboline Conjugates on NMDA Receptors}

The glutamatergic system of the central nervous system (CNS) is known to play a key role in memory consolidation and neurodegenerative processes leading to impairment of cognitive functions and memory during such diseases as AD and senile dementia [24]. Ionotropic glutamate receptors coupled to ion channels, in particular NMDA-subtype glutamate receptors, play an important role in these processes [25-27]. Compounds that are able to block NMDA receptors have long been considered as potential treatments for neurodegenerative diseases [28-30]. The drug memantine, the best-known NMDA receptor blocker, is used in clinical practice to improve memory and cognitive functions in patients with later stages of $\mathrm{AD}$ and some other diseases [14,31]. It is assumed that memantine interacts mainly with the binding site within the NMDA receptor ion channel [32]. Specific (allosteric) binding sites on NR2B subunits of the NMDA receptor are considered as another potential target in the search for neuroprotective and cognitive-enhancing agents. The NR2B subunit is involved in neurodegenerative processes in patients with Parkinson's and Huntington's diseases as well as AD [33]. Therefore, efficient modulators of GluN2Bcontaining NMDARs are a promising tool for further investigation and potential treatment of these diseases [34-36].

The effect of the synthesized compounds on the two binding sites of the NMDA receptor, namely, the intrachannel (MK-801-binding) and peripheral (ifenprodil-binding) sites, was studied by a radiolabeled ligand displacement assay using $\left[{ }^{3} \mathrm{H}\right]-\mathrm{MK}-801$ and $\left[{ }^{3} \mathrm{H}\right]$-ifenprodil as radioactive-labeled specific ligands, respectively). The results are summarized in Table 1.

Based on the results in Table 1, the following conclusions can be made about the effect of the spacer structure and the pharmacophore scaffolds on anti-NMDA activity:

In all cases, the use of the 1-oxoethylene spacer instead of the ethylene one substantially (by 1-1.5 orders of magnitude) impairs the binding of the compounds to both sites of the NMDA receptor.

Compounds bearing the ethylene spacer (4a-4f) have similar $K_{\mathrm{i}}$ values in the micromolar range almost regardless of the nature of the substituents in the polycyclic moieties (conjugated scaffolds). The $K_{\mathrm{i}}$ values toward the MK-801-binding site for these compounds are close to that for memantine, for which this binding site of the NMDA receptor is the main target of action. In particular, monomethyl-substituted 1,2,3,4-tetrahydro- $\gamma$-carbolines (compounds $\mathbf{4 a}$ and $\mathbf{4 d}$ ) are the most active compounds in this respect.

Unexpectedly, the compounds bearing the ethylene spacer (4a-4f) show high (micromolar) activity toward the ifenprodil-binding site of the NMDA receptor, as opposed to memantine and dimebon, which, being structural analogs of conjugated polycyclic scaffolds, do not exhibit specific activity toward this site of the NMDA receptor. 
Table 1. Binding of compounds to MK-801-specific and Ifenprodil-specific sites of NMDA receptors.

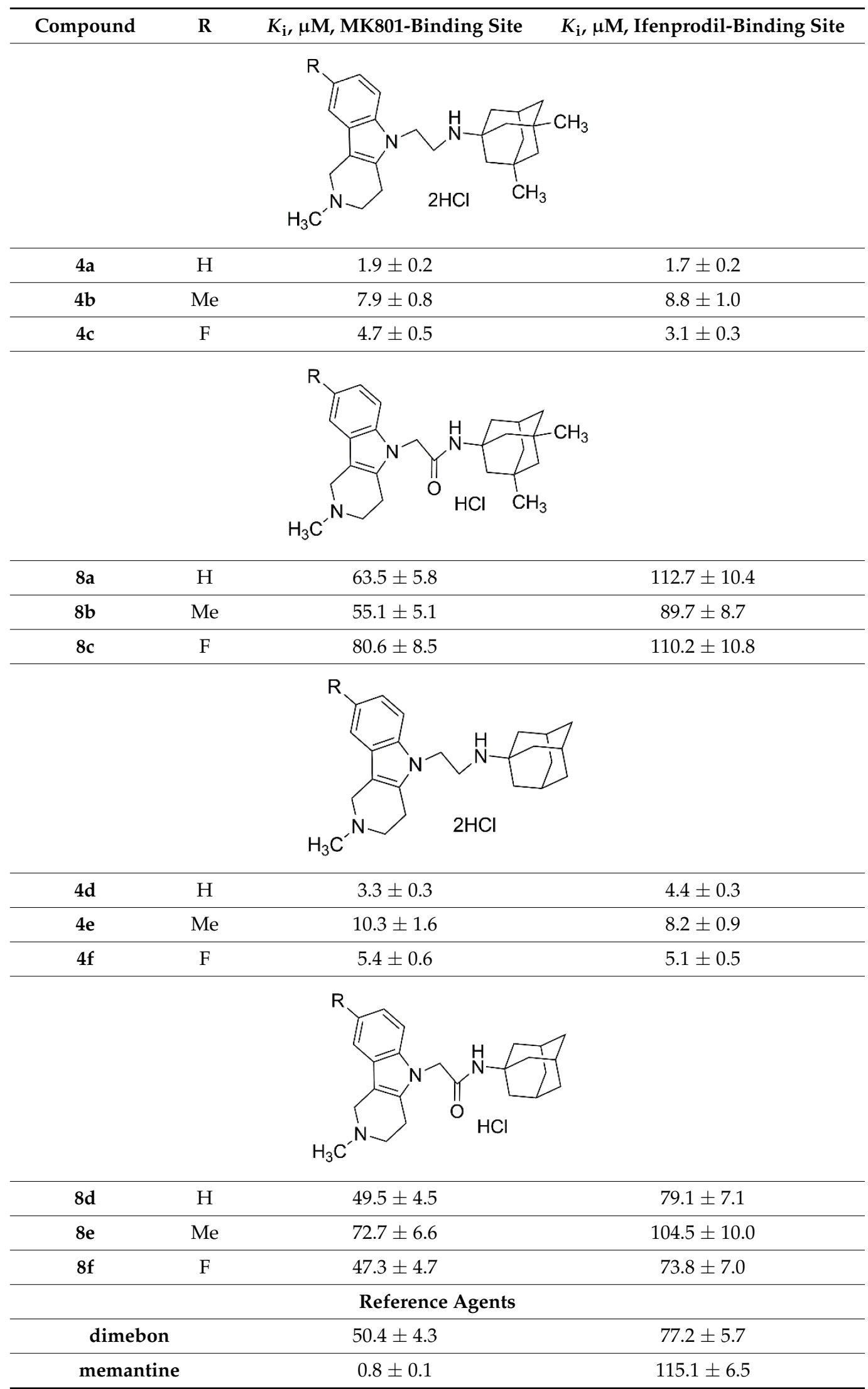




\subsection{Esterase Profiles of Aminoadamantane- $\gamma$-Carboline Conjugates and Their Ability to Displace} Propidium Iodide from the AChE PAS

Cholinergic deficit is a characteristic feature of AD. It is associated with the selective loss of cholinergic neurons in the nucleus basalis of Meynert in early stages of the disease and is largely responsible for the impairment of cognitive functions [37,38]. Inhibitors of AChE suppress its classical function of hydrolysis of the neurotransmitter acetylcholine, resulting in an increase in the activation of cholinergic neurons and stimulation of cognitive functions [37,39].

The inhibition of another cholinesterase, $\mathrm{BChE}$, also facilitates the improvement of cognitive functions. It is worth noting that $\mathrm{BChE}$ inhibition is particularly effective in the case of disease progression, when $\mathrm{AChE}$ activity decreases, while $\mathrm{BChE}$ activity gradually increases. Hence, $\mathrm{BChE}$ is of great interest as a therapeutic target for decreasing the cholinergic deficit $[40,41]$ in advanced stages of the disease. It should be emphasized that selective $\mathrm{BChE}$ inhibitors increase the acetylcholine level in the brain, having no classical side effects typical of $\mathrm{AChE}$ inhibitors [42,43]. Therefore, considerable recent attention has been focused on the search for selective $\mathrm{BChE}$ inhibitors, as well as compounds inhibiting both cholinesterases, $\mathrm{AChE}$ and $\mathrm{BChE}$, because in this case the effective therapeutic action would be expected to be retained both in early and later stages of AD progression [42,44,45].

In the current study, the evaluation of the esterase profile of the new compounds included also the determination of inhibitory activity against carboxylesterase (CES), which is structurally similar to cholinesterases. This enzyme catalyzes the hydrolysis of many drugs containing ester groups [46,47] and is considered as an anti-target, because the ability of anticholinesterase agents, used in the treatment of AD, to inhibit CES can lead to unwanted drug-drug interactions.

Another important aspect of the action of cholinesterase inhibitors is associated with the aggregation and deposition of $\beta$-amyloid peptides in the brain, which plays a key role in the appearance and progression of $\mathrm{AD}[48,49]$. It was shown that, apart from the classical function of acetylcholine hydrolysis, $\mathrm{AChE}$ exhibits $\beta$-amyloid proaggregation activity [50] due to the ability of the PAS of the enzyme to interact with soluble $\beta$-amyloid peptides, thereby promoting their aggregation [9,51-54]. Hence, AChE inhibitors that interact with the AChE PAS can be considered as potential antiaggregation agents [53,55-57]. It is assumed that $\mathrm{BChE}$ is also involved in the formation and/or maturation of $\beta$-amyloid plaques, thereby contributing to the pathogenesis of AD [58-61]. Therefore, AChE inhibitors and inhibitors of both cholinesterases are of interest in anti-amyloid strategies.

\subsubsection{Evaluation of the Esterase Profile of Aminoadamantane- $\gamma$-Carboline Conjugates}

To evaluate the esterase profiles of aminoadamantane- $\gamma$-carboline conjugates, their inhibitory activity against three structurally similar serine esterases, AChE, BChE and CES was determined. We used human erythrocyte AChE, equine serum BChE and porcine liver CES, which were shown to be suitable for this purpose in our previous studies $[11,12,47,62,63]$. The results showed (Table 2) that all of the conjugates were more potent inhibitors of $\mathrm{BChE}$ compared to $\mathrm{AChE}$ and that they had very weak inhibitory activity against $C E S$. The conjugates containing the memantine fragment were somewhat more effective than their amantadine analogs as $\mathrm{BChE}$ inhibitors.

The spacer structure had an appreciable effect on the inhibitory activity of the conjugates. Conjugates 4 linked via the ethylene spacer were effective and selective $\mathrm{BChE}$ inhibitors. The replacement of the ethylene spacer by the 1-oxoethylene one (conjugates 8) led to a decrease in BChE inhibition (see Table 2, evidenced by the comparison of $\mathbf{4 a - c}$ and $\mathbf{8 a}-\mathbf{c}, \mathbf{4} \mathbf{d}-\mathbf{f}$ and $\mathbf{8 d}-\mathbf{f})$. Regarding the effect of the structure of the $\gamma$-carboline fragment, the 2-Me and 2-Me, 8-F derivatives exhibited the highest activity in all four groups. Conjugates $4 \mathbf{a}$ and $\mathbf{4} \mathbf{c}$ that inhibited $\mathrm{BChE}$ in the submicromolar concentration range were the most effective. 
Table 2. Esterase profiles of aminoadamantane- $\gamma$-carboline conjugates and their ability to displace propidium iodide from the AChE PAS.

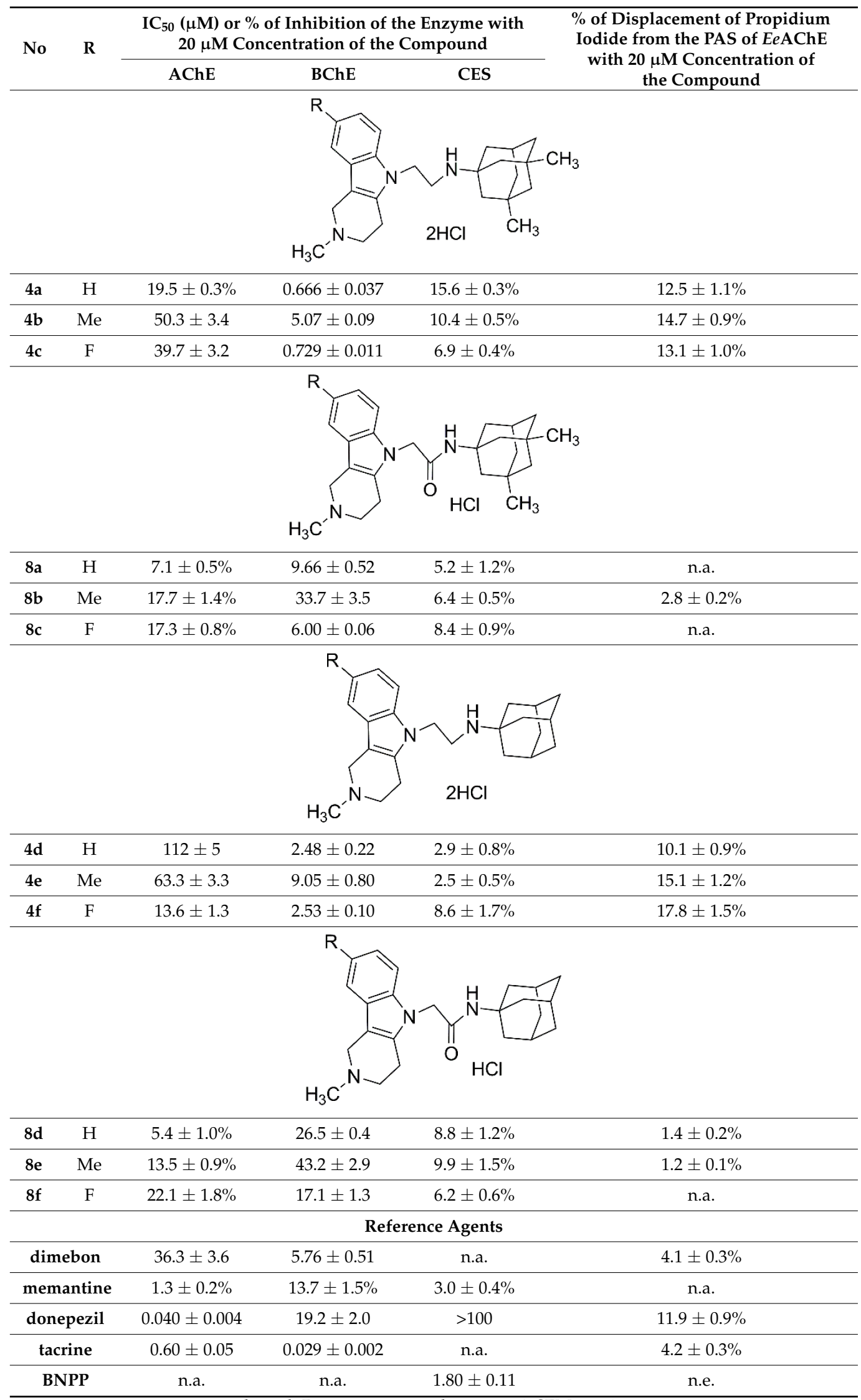

n.a. $=$ not active. n.e. $=$ not evaluated. Data are expressed as mean \pm SEM, $n=3$. 
Whereas the synthesized conjugates were more effective against BChE than AChE, the spacer structure also had an appreciable effect on the inhibitory activity of the conjugates against AChE. Conjugates 4 linked via an ethylene spacer were modest AChE inhibitors. However, their analogs 8 linked via the oxoethylene spacer were substantially less effective, and at a concentration of $20 \mu \mathrm{M}$, the degree of inhibition varied from 5 to $22 \%$ (see Table 2).

\subsubsection{Kinetic Studies of AChE and BChE Inhibition}

Studies of the kinetics and mechanism of AChE and BChE inhibition by the synthesized aminoadamantane- $\gamma$-carboline conjugates were conducted using compound $4 \mathrm{c}$. The graphical analysis of the kinetic data on AChE (Figure 2a) and BChE (Figure 2b) inhibition by compound $4 \mathrm{c}$ by Lineweaver-Burk double-reciprocal plots showed changes in both $K_{\mathrm{m}}$ and $V_{\max }$, which is indicative of a mixed type of inhibition. Inhibition constants for AChE were $13.70 \pm 0.02 \mu \mathrm{M}\left(K_{\mathrm{i}}\right.$, the competitive component) and $45.5 \pm 3.8 \mu \mathrm{M}\left(\alpha K_{\mathrm{i}}\right.$, the non-competitive component). Corresponding values for BChE were $0.23 \pm 0.02 \mu \mathrm{M}\left(K_{\mathrm{i}}\right)$ and $0.70 \pm 0.01 \mu \mathrm{M}\left(\alpha K_{\mathrm{i}}\right)$.

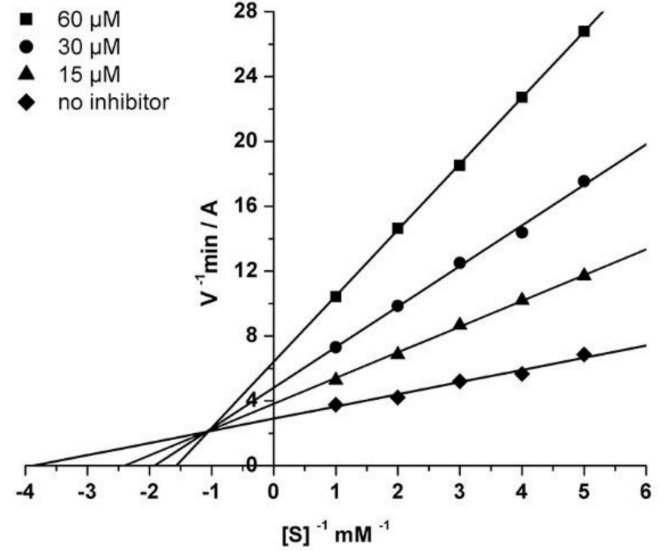

(a)

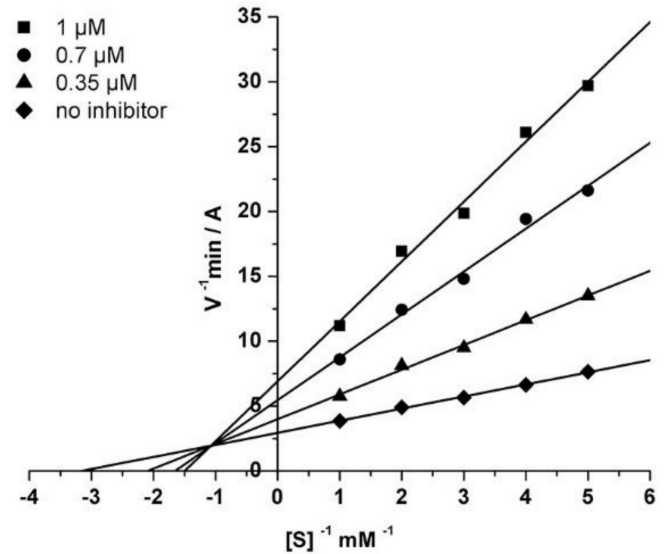

(b)

Figure 2. Kinetics of the steady-state inhibition of AChE (a) and BChE (b) by compound 4c. The data are presented as Lineweaver-Burk double-reciprocal plots.

\subsubsection{Molecular Docking to BChE}

The molecular docking of the conjugates to BChE accounts for some of the observed structure-activity relationships. Even though binding energies could not be directly related to $\mathrm{IC}_{50}$ values [64], the rank order of docking scores for the most potent 4 compounds and the least potent compound against $\mathrm{BChE}$ were in agreement with the rankings for experimentally determined potencies. (Table S1). Moreover, the docking scores and inhibitor potencies for all compounds were well correlated after converting $\mathrm{IC}_{50}$ values to pIC $_{50}$ values: $\mathrm{r}=0.725 ; p=0.003 ; n=14$ ( $\mathrm{r}$-Pearson correlation coefficient, which can be used because in this case, both the $\mathrm{pIC}_{50}$ and the docking scores were normally distributed).

It was found that memantine and amantadine fragments were bound within the active site gorge of BChE so that the protonated aminoadamantane group of conjugates 4 linked via the ethylene spacer formed an ion pair with Asp70 (Figure 3a). In contrast, the relevant group in conjugates 8 linked via the 1-oxoethylene spacer is an amide; consequently, it is non-charged, resulting in a decrease in the number of specific interactions, thus explaining the observed reduction of inhibitory activity (see Figure 3a). The hydrophobic pocket within the active site gorge of $\mathrm{BChE}$ was the best-docked pose of the amantadine/memantine group, as discussed previously for memantine-carbazole conjugates [9]. The presence of the amantadine/memantine group alters the position of the $\gamma$-carboline fragment of conjugates compared to the binding pose of their prototype dimebon (Figure S1a). However, the 
binding pose of compound 8a with the 1-oxoethylene spacer was very close to that of the reference compound donepezil (Figure S1b).

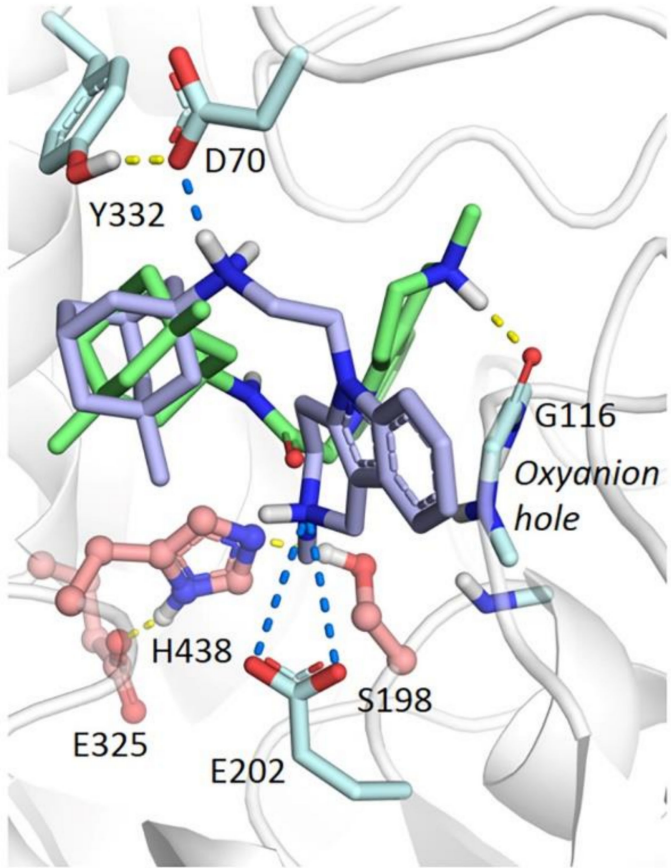

(a)

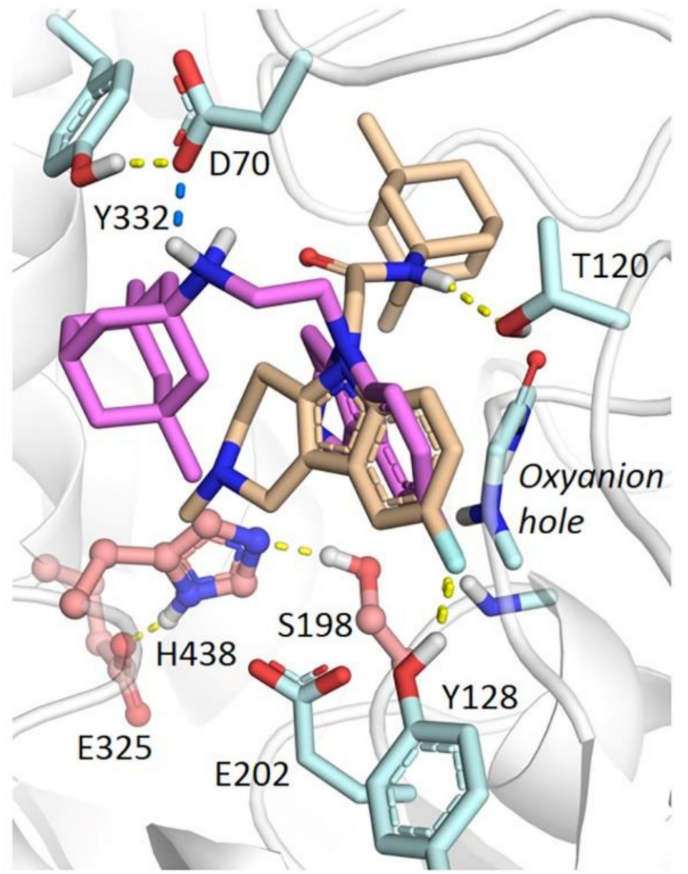

(b)

Figure 3. Docking of conjugates linked via ethylene and 1-oxoethylene spacers to BChE: (a), comparison of $4 \mathbf{a}$, the ethylene spacer (carbon atoms are shown in light blue) and 8a the 1-oxoethylene spacer (light green); (b), comparison of $4 \mathbf{c}$, the ethylene spacer (purple) and $8 \mathbf{c}$, the 1-oxoethylene spacer (sandy colored).

For the conjugates linked via the 1-oxoethylene spacer, another, although somewhat less stable, binding pose is also possible. In this pose, the memantine group points toward the entrance of the active site gorge, thereby providing hydrogen bonding between the amide group and Thr120 (see Figure 3b).

A comparative docking to the active site of $\mathrm{BChE}$ of compounds $4 \mathrm{~b}$ and $4 \mathrm{c}$, which differ by the structure of the $\gamma$-carboline fragment, demonstrated that the fluorine atom could act as an acceptor of a hydrogen bond with Tyr128. This interaction improves the binding of conjugate $4 c$ [65] compared to the dimethyl derivative $4 \mathrm{~b}$ and is responsible for its higher inhibitory activity (Figure 4).

\subsubsection{Molecular Docking to AChE}

The molecular docking to AChE was performed for conjugates 4 with memantine $(4 b, c)$ and amantadine (4e,f) fragments linked via the ethylene spacer. The best binding pose was obtained with the amantadine/memantine group bound in the catalytic active site (CAS) of AChE and the $\gamma$-carboline group partially occupying the PAS (Figure 5a). Here, the amantadine/memantine moiety takes the place of the phenyl group of donepezil, the reference compound (Figure S2a). The docked position of donepezil was identical to the binding pose obtained with X-ray crystallography [66,67]. A clear difference in $\pi-\pi$ interactions with $\operatorname{Trp} 86$ and Trp286 could contribute to the lower binding affinities of compounds 4 compared to donepezil. Moreover, taking into account that the CAS of AChE is separated from the PAS by the so-called bottleneck, the penetration of the bulky amantadine/memantine group (much bigger than phenyl) into the CAS could be kinetically hindered [68]. Consequently, the binding pose ranked second in energy, with the amantadine/memantine group in the PAS (Figure 5b), seemed more reasonable and should ensure efficient displacement of the selective PAS ligand, propidium iodide. Here it also overlapped with the position of donepezil (Figure S2b). In this case, the $\gamma$-carboline group 
could bind to both the PAS and CAS, and these poses were characterized by similar binding energies. Compared with the docked pose of dimebon, the positions of the $\gamma$-carboline fragments of conjugates 4 in the CAS were identical (Figure S2b). Overall, these docking results were in good agreement with the results of the kinetic study of inhibition, which showed a mixed type of inhibition.

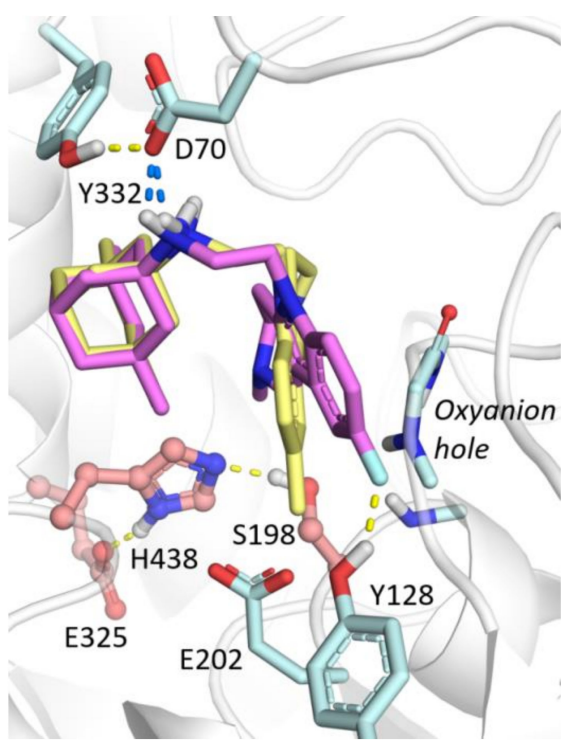

Figure 4. Docking of memantine derivatives, which differ by the structure of the $\gamma$-carboline fragment, to BChE: 2-Me, 8-F derivative $4 \mathrm{c}$ (carbon atoms are shown in purple) and its dimethyl analog $4 \mathrm{~b}$ (carbon atoms are shown in yellow).

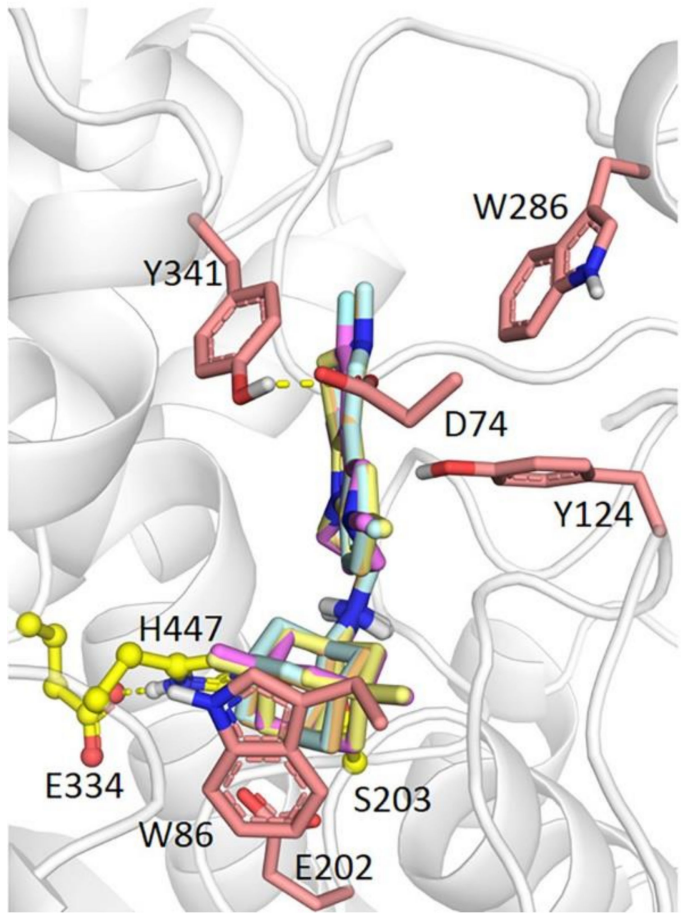

(a)

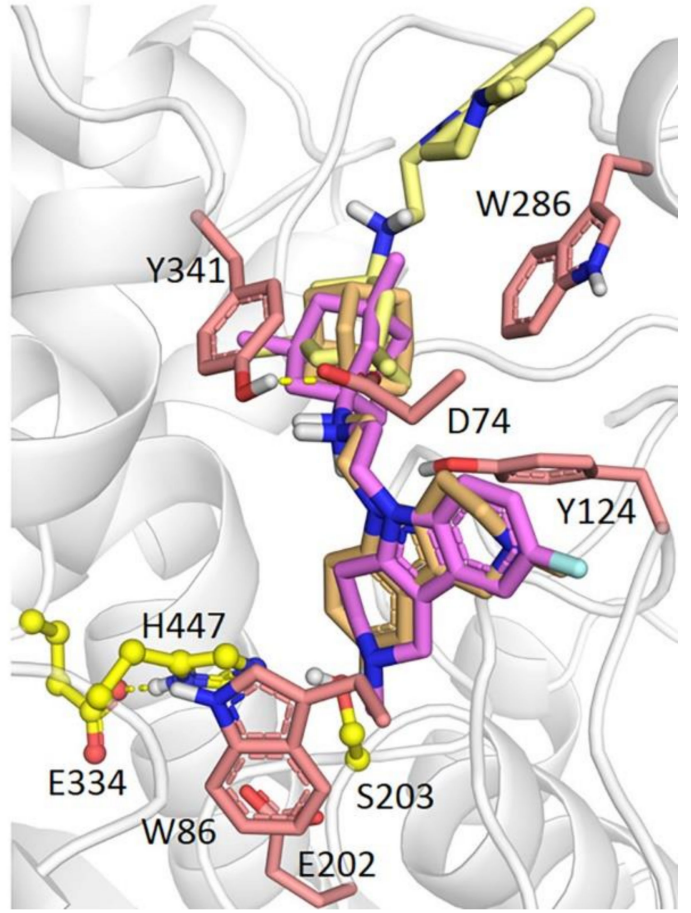

(b)

Figure 5. Docking of memantine and amantadine derivatives linked via the ethylene spacer to AChE (carbon atoms are shown in yellow for $\mathbf{4 b}$, blue for $\mathbf{4 e}$, purple for $\mathbf{4 c}$ and orange for $\mathbf{4 f}$ ). Panel (a): the best energy-scored pose based on molecular docking, which could be kinetically hindered. Panel (b): the binding pose ranked second in energy, with the amantadine/memantine group bound to the PAS. The $\gamma$-carboline group can bind to both the CAS and PAS. 
2.3.5. Evaluation of Conjugates Ability to Displace Propidium Iodide from the EeAChE PAS

Taking into account the $\beta$-amyloid proaggregation properties of $\mathrm{AChE}$ [50], we evaluated conjugates 4 and $\mathbf{8}$ for their ability to displace the selective PAS ligand, propidium iodide, from the EeAChE PAS. This method is widely used as a screening approach to assess the potential ability of compounds to block AChE-induced $\beta$-amyloid aggregation, because when the compounds bind to the AChE PAS, they prevent the binding of $\beta$-amyloid, thereby inhibiting its aggregation [53,55,69-73]. The method is described in detail in [74]. EeAChE was used owing to its high degree of purification, high activity, lower cost than human AChE and essential congruence of the two enzyme structures [74]. Donepezil, a mixed-type AChE inhibitor, for which the ability to block AChE-PAS-induced A $\beta$ aggregation has been demonstrated [53], was used as a reference compound. The results are presented in Table 2 .

Conjugates 4 linked via the ethylene spacer exhibited activities equal to or higher than that of donepezil. They displaced propidium iodide from the EeAChE PAS by 10-18\%. Meanwhile, conjugates 8 linked via the 1-oxoethylene spacer very poorly inhibited the catalytic activity of $\mathrm{AChE}$ and, in general, could not effectively displace propidium.

Therefore, the data on the displacement of propidium iodide from the AChE PAS and the results of kinetic studies and molecular docking show that conjugates 4 linked via the ethylene spacer can bind to both the CAS and the PAS of AChE. Due to binding to the AChE PAS, compounds 4, apart from effective BChE inhibition and moderate AChE inhibition, could potentially block AChE-induced $\beta$-amyloid aggregation and thereby exhibit a disease-modifying effect.

\subsection{Effect of Aminoadamantane- $\gamma$-Carboline Conjugates on the Functional Properties of Isolated Rat Liver Mitochondria}

In the drug design for the treatment of NDs, an important issue is to provide neuroprotective effects against processes causing cell death. A promising target for such activity is the MPT, a key step in the cell death cascade implicated in neurodegeneration [75,76]. According to some authors, the neuroprotective action of dimebon, a prototype of the $\gamma$-carboline pharmacophore contained in our conjugates, could be ascribed to its ability to increase the resistance of mitochondria to the induction of the MPT [18-20]. Consistent with this view, our primary panel of mitochondrial tests showed promise in the search for new drugs for the treatment of NDs [77,78], and these results were echoed in our studies of bipharmacophoric compounds $[8,9,12]$ and related indole-aminoadamantane conjugates [9].

To assess the interactions of the new conjugates with mitochondria, we evaluated their effects on mitochondrial membrane potential in the presence of substrates of complex I (glutamate and malate) and complex II (succinate) of the mitochondrial respiratory chain. None of the tested compounds affected the membrane potential of isolated mitochondria; moreover, all of them reduced spontaneous depolarization. Furthermore, the conjugates decreased calcium-induced mitochondrial depolarization. These results indicated that these compounds lacked mitochondrial toxicity and allowed us to suggest the possibility of a protective effect, such as prevention of the induction of the MPT.

Therefore, in the next step, we evaluated the effect of the tested compounds on $\mathrm{Ca}^{2+}$-induced mitochondrial swelling, a reflection of the opening of the MPT pore. Inhibition of MPT pore opening would be an important indicator of potential neuroprotective activity. The results are summarized in Table 3. All conjugates exhibited MPT-inhibitory activity. Under these conditions, the efficacy of a number of the conjugates was similar to or even somewhat higher than that of dimebon. The conjugates linked via the ethylene spacer (4a-f) more effectively decreased the maximum rate of mitochondrial swelling at a concentration of $30 \mu \mathrm{M}$ (by more than $70 \%$ relative to the reference compound, which is comparable with the activity of dimebon). However, the introduction of the 1-oxoethylene spacer reduced the ability to suppress the MPT. 
Table 3. Effects of compounds on the calcium-induced MPT pore opening and the rate of GTPdependent $\mathrm{Tb}+\mathrm{MAP}$ polymerization.

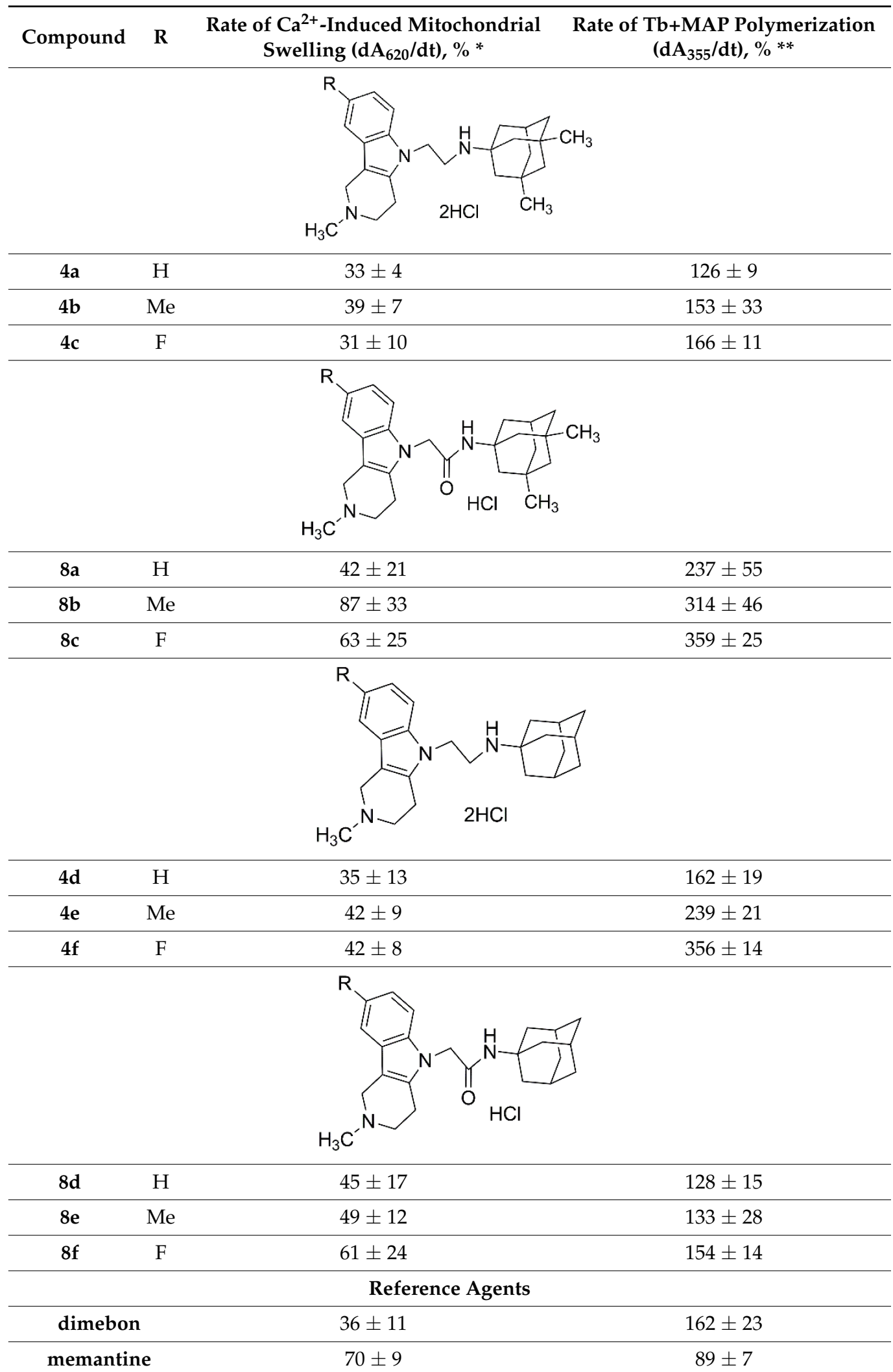

* The effect of $30 \mu \mathrm{M}$ compounds on the maximum rate of $\mathrm{Ca}^{2+}$-induced swelling of isolated mitochondria $\left.\left(\mathrm{dA}_{620} / \mathrm{dt}\right), \%\right)$. Data are presented as the percentage relative to the reference compound; the $\mathrm{Ca}^{2+}$ concentration was $12.5 \mu \mathrm{M}$; the following mixture of substrates was used: $10 \mathrm{mM}$ glutamate, $2 \mathrm{mM}$ malate and $10 \mathrm{mM}$ succinate ** The effect of $100 \mu \mathrm{M}$ compounds on the rate of $\mathrm{Tb}+\mathrm{MAP}$ polymerization $\left.\left(\mathrm{dA}_{355} / \mathrm{dt}\right), \%\right)$. 
The concentration dependences of the inhibition of $\mathrm{Ca}^{2+}$-induced swelling (Figure 6) of mitochondria in the presence of different substrates of the mitochondrial respiratory chain were determined for a pair of active compounds $\mathbf{4 c}$ and $\mathbf{4 f}$, which differed in the type of aminoadamantyl substituent. The results were indicative of the inhibitory effect on the $\mathrm{Ca}^{2+}$-induced mitochondrial pore opening. The conjugates more effectively inhibited $\mathrm{Ca}^{2+}$-dependent MPT pore opening in the presence of the substrate of complex II and the inhibitor rotenone of complex I (Figure 6a) compared to mitochondria energized by glutamate and malate (Figure 6b). It is worth noting that compound $4 \mathrm{c}$ containing the dimethylaminoadamantyl (memantine) substituent had stronger mitoprotective properties than $\mathbf{4 f}$ with aminoadamantyl fragment.

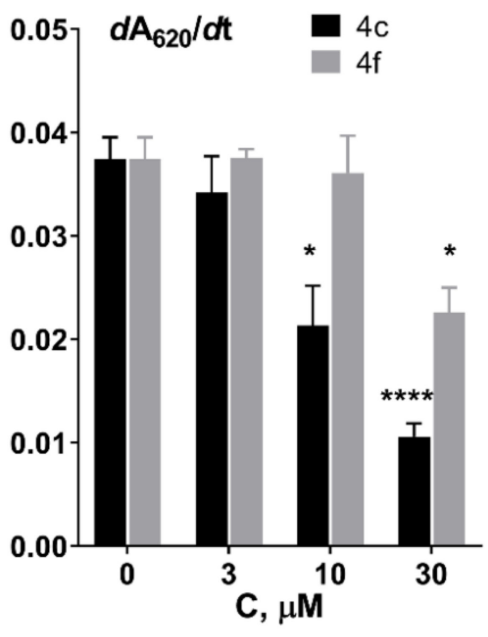

(a)

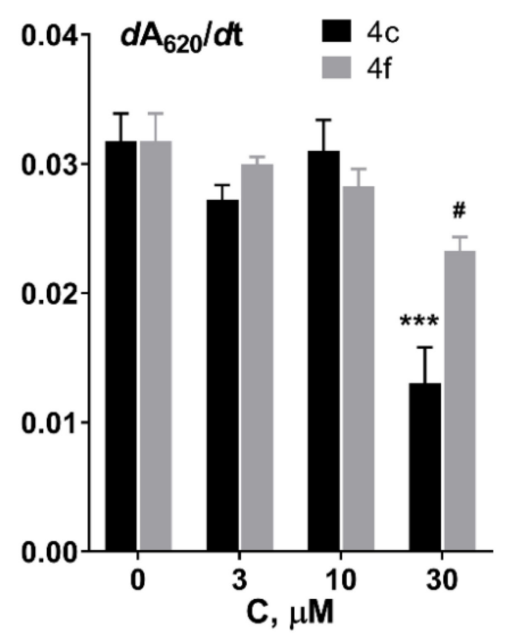

(b)

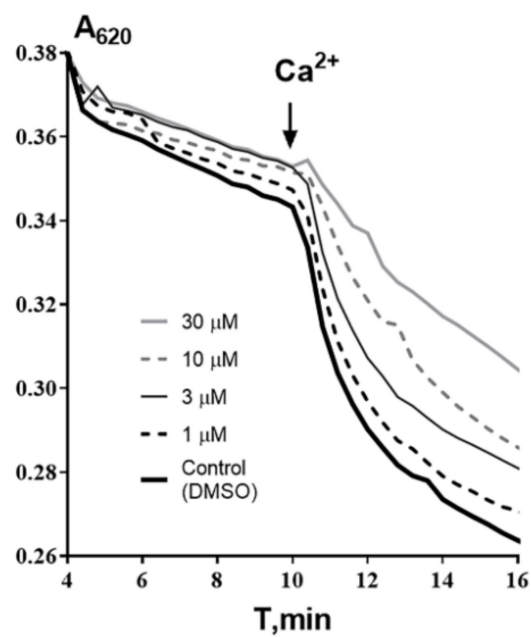

(c)

Figure 6. Effect of compounds $4 \mathrm{c}$ and $4 \mathrm{f}$ on the rate of $\mathrm{Ca}^{2+}$-induced mitochondrial swelling. (a) in the presence of the substrate of complex II and the inhibitor rotenone of complex I. (b) compared to mitochondria energized by glutamate and malate. (c) representative curve of $4 \mathbf{c}$ influence on the kinetics of mitochondrial swelling in the presence of the substrate of complex II and the inhibitor rotenone of complex I. The $\mathrm{Ca}^{2+}$ concentration was $12.5 \mu \mathrm{M}$. The significance of the differences was estimated by two-factor dispersion analysis ANOVA with Tukey's post-hoc multiple comparison test $\left({ }^{*} p \leq 0.05\right.$, ${ }^{* * *} p \leq 0.001,{ }^{* * * *} p \leq 0.0001$, comparison with the control group) and Student's $t$-test (\# $p \leq 0.05$, comparison with the control group).

After the addition of the tested compounds to a suspension of mitochondria, the spontaneous depolarization was significantly inhibited compared to the control group (data not shown). There are many possible mechanisms of this effect; the most probable being reduction of spontaneous MPT pore opening, suppression of free radical production by mitochondria or inhibition of membrane lipid peroxidation [79].

It should also be noted that the conjugates showed no cytotoxic properties in the evaluation of the effect of $30 \mu \mathrm{M}$ of tested compounds on the viability of SH-SY5Y neuroblastoma cells by the MTT assay: the percentage of mitochondrial dehydrogenase activity in the test cells with the conjugates did not differ from that in the control (data not shown).

\subsection{Effect of Aminoadamantane- $\gamma$-Carboline Conjugates on Tubulin Polymerization}

Previously, we found compounds in the series of indole-aminoadamantane conjugates, namely tetrahydrocarbazole-aminoadamantane conjugates, which could significantly stimulate tubulin polymerization to form microtubules with normal structure [9]. The stabilization of microtubules as a compensation of the impaired function of the microtubuleassociated $\tau$-protein, which is caused by its hyperphosphorylation and aggregation, is a highly promising disease-modifying therapy for tauopathies as NDs [80].

Therefore, we performed primary screening of this series of aminoadamantane- $\gamma$ carboline conjugates for their effect on the polymerization of a crude preparation of tubu- 
lin and microtubule-associated proteins (Tb+MAP). An increase in the rate of Tb+MAP polymerization was observed for all the conjugates under study. For the most active fluorine-containing conjugates $4 \mathrm{f}$ and $8 \mathrm{c}$ linked via the ethylene and oxoethylene spacer, respectively, the rate of $\mathrm{Tb}+\mathrm{MAP}$ polymerization increased by more than a factor of 3.5 (see Table 3 and Figure 7). In the series of the conjugates linked via the oxoethylene spacer, the conjugates containing the dimethylaminoadamantyl (memantine) moiety caused the most substantial increase in the polymerization rate. In contrast, in the series of conjugates linked via the ethylene spacer, the compounds containing the unsubstituted adamantyl group were found to be the most active. The replacement of the methyl substituent at the 8-position of the $\gamma$-carboline ring with fluorine did not lead to an appreciable change in the activity of the compounds.

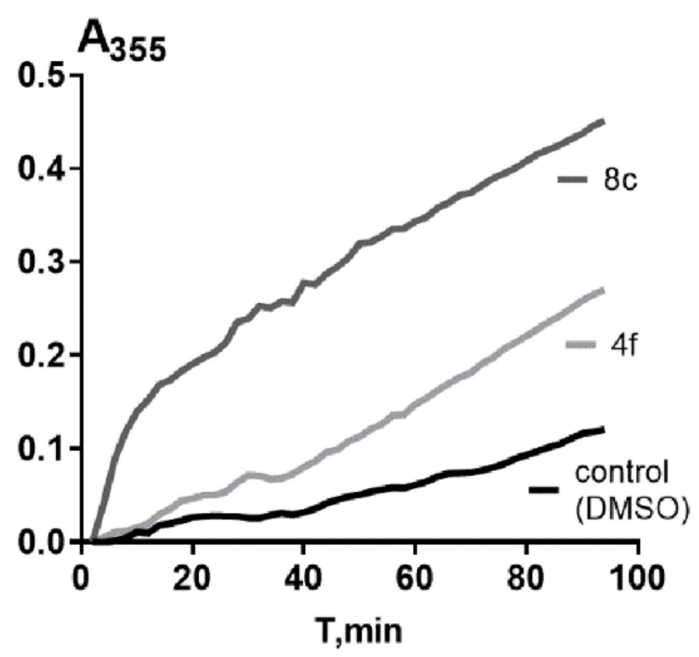

Figure 7. Representative curves of effect of compounds 8c and 4f on GTP-dependent $\mathrm{Tb}+\mathrm{MAP}$ polymerization.

\section{Materials and Methods}

\subsection{Synthesis Method and Spectral Data}

FT IR spectra were obtained on a Bruker IFS-113v spectrometer (Bruker Analytik $\mathrm{GmbH}$, Silberstreifen, Germany) and recorded as $\mathrm{KBr}$ pallets with absorptions reported as $\mathrm{cm}^{-1}$. The ${ }^{1} \mathrm{H},{ }^{13} \mathrm{C}$ and ${ }^{19} \mathrm{~F}$ NMR spectra were recorded on a Bruker DXP spectrometer (Bruker, Billerica, MA, USA) at 200, 50 and $188 \mathrm{MHz}$, respectively, in DMSO- $\mathrm{d}_{6}$ using tetramethylsilane as an internal standard and $\mathrm{CCl}_{3} \mathrm{~F}$ as an external standard. Chemical shifts are reported in ppm on the $\delta$ scale. Coupling constants are given in Hertz $(\mathrm{Hz})$. Melting points were measured in open capillary tubes with a STUART SMP20 melting point apparatus (Cole-Parmer, Vernon Hills, IL, USA) and uncorrected. The elemental analysis was carried out on an Elementar vario MICRO cube CHNS/O analyzer. Chromatography was performed on Alfa Aesar 220-440 mesh silica gel. The synthesis of compounds $\mathbf{1 a}-\mathbf{c}$ was described in [23]. Gamma-carbolines $\mathbf{5 a - c}$ were prepared as described in [81]; chloroacetylamides $\mathbf{6} \mathbf{a}, \mathbf{b}$, in [82].

\subsubsection{General Procedure for the Preparation of Compounds $4 \mathbf{a}-\mathbf{f}$}

Solutions of compound 1a-c $(1 \mathrm{mmol})$ and 1-aminoadamantane 2 (1 mmol) in i-PrOH $(10 \mathrm{~mL})$ were placed in sealed tubes and heated for 3 days at $140{ }^{\circ} \mathrm{C}$. The solvent was evaporated, and the residue was purified by column chromatography on silica gel (60 mesh, methanol-chloroform, 1:10, as the eluent). To a solution of compound $3(0.5 \mathrm{mmol})$ in acetone $(5 \mathrm{~mL}), 37 \%(v / v) \mathrm{HCl}(0.1 \mathrm{~mL})$ was added, and the precipitate that formed was filtered off.

3,5-Dimethyl-N-(2-(2-methyl-3,4-dihydro-1H-pyrido[4,3-b]indol-5(2H)-yl)ethyl)adamantane-1-amine dihydrochloride (4a). Brown solid. Yield 35\%. Mp 206-207 ${ }^{\circ} \mathrm{C}$. 
FT IR $\left(\mathrm{KBr} \gamma_{\max }\right.$ in $\left.\mathrm{cm}^{-1}\right)$ : $3432(\mathrm{NH}), 2914\left(\mathrm{CH}_{2}\right), 2854\left(\mathrm{NCH}_{3}\right), 1618(\mathrm{C}=\mathrm{C}), 1454(\mathrm{CH}$ of $\left.\mathrm{CH}_{2}\right) .{ }^{1} \mathrm{H}$ NMR $\left(200 \mathrm{MHz}, \mathrm{DMSO}-\mathrm{d}_{6}\right): \delta=0.85\left(\mathrm{~s}, 6 \mathrm{H}, \mathrm{C}_{\mathrm{Ad}} \mathrm{H}_{3}\right), 1.00-1.22(\mathrm{~m}, 2 \mathrm{H}$, $\left.\mathrm{C}_{\mathrm{Ad}} \mathrm{H}_{2}\right), 1.22-1.44\left(\mathrm{~m}, 4 \mathrm{H}, \mathrm{C}_{\mathrm{Ad}} \mathrm{H}_{2}\right), 1.46-1.84\left(\mathrm{~m}, 6 \mathrm{H}, \mathrm{C}_{\mathrm{Ad}} \mathrm{H}_{2}\right), 2.16\left(\mathrm{~m}, 1 \mathrm{H}, \mathrm{C}_{\mathrm{Ad}} \mathrm{H}\right), 3.14$ $\left(\mathrm{s}, 3 \mathrm{H}, \mathrm{CH}_{3} \mathrm{~N}\right), 3.38-3.70\left(\mathrm{~m}, 4 \mathrm{H}, \mathrm{CH}_{2}\right), 3.81-4.12\left(\mathrm{~m}, 1 \mathrm{H}, \mathrm{CH}_{2}\right), 4.20-4.42\left(\mathrm{~m}, 1 \mathrm{H}, \mathrm{CH}_{2}\right)$, 4.94-5.20 (m, $\left.1 \mathrm{H}, \mathrm{CH}_{2}\right), 5.35-5.70\left(\mathrm{~m}, 3 \mathrm{H}, \mathrm{CH}_{2}\right), 7.04-7.23\left(\mathrm{~m}, 2 \mathrm{H}, \mathrm{CH}_{\mathrm{Ar}}\right), 7.46\left(\mathrm{~d}, 1 \mathrm{H}, \mathrm{C}_{\mathrm{Ar}} \mathrm{H}\right.$, $\left.{ }^{3} J_{\mathrm{HH}}=7.7 \mathrm{~Hz}\right), 7.69\left(\mathrm{~d}, 1 \mathrm{H}, \mathrm{C}_{\mathrm{Ar}} \mathrm{H},{ }^{3} J_{\mathrm{HH}}=7.7 \mathrm{~Hz}\right), 10.65$ (br. S, $\left.2 \mathrm{H}, \mathrm{NH}\right), 13.80$ (br. S, $1 \mathrm{H}$, $\left.\mathrm{NH}^{+} \mathrm{CH}_{3}\right) .19 .25\left(\mathrm{CH}_{2}\right), 29.43(\mathrm{CH}), 29.96\left(\mathrm{CH}_{3}\right), 31.90(\mathrm{C}), 36.06\left(\mathrm{CH}_{2}\right), 37.72\left(\mathrm{CH}_{2}\right), 41.42$ $\left(\mathrm{CH}_{2}\right), 41.52\left(\mathrm{CH}_{2}\right), 43.24\left(\mathrm{CH}_{3}\right), 49.08\left(\mathrm{CH}_{2}\right), 49.46\left(\mathrm{CH}_{2}\right), 49.90\left(\mathrm{CH}_{2}\right), 57.94(\mathrm{C}), 101.64(\mathrm{C})$, 109.33 (CH), 117.28 (CH), $119.23(\mathrm{CH}), 121.37(\mathrm{CH}), 124.15(\mathrm{C}), 130.56(\mathrm{C}), 135.61(\mathrm{C})$. Anal. C 67.42, H 8.66, N 9.21\%. Calcd. For $\mathrm{C}_{26} \mathrm{H}_{39} \mathrm{Cl}_{2} \mathrm{~N}_{3}, \mathrm{C} 67.23, \mathrm{H}$ 8.46, N 9.05\%.

$N$-(2-(2,8-Dimethyl-3,4-dihydro-1H-pyrido[4,3-b]indol-5(2H)-yl)ethyl)-3,5dimethyladamantane-1-amine dihydrochloride (4b). Brown solid. Yield $34 \%$. Mp 205-206 ${ }^{\circ} \mathrm{C}$. FT IR (KBr $v_{\max }$ in $\left.\mathrm{cm}^{-1}\right)$ : $3432(\mathrm{NH}), 2906\left(\mathrm{CH}_{2}\right), 2842\left(\mathrm{NCH}_{3}\right), 1622(\mathrm{C}=\mathrm{C}), 1457(\mathrm{CH}$ of $\left.\mathrm{CH}_{2}\right) .{ }^{1} \mathrm{H}$ NMR $\left(200 \mathrm{MHz}, \mathrm{DMSO}-\mathrm{d}_{6}\right): \delta=0.84\left(\mathrm{~s}, 6 \mathrm{H}, \mathrm{C}_{\mathrm{Ad}} \mathrm{H}_{3}\right), 1.02-1.18\left(\mathrm{~m}, 2 \mathrm{H}, \mathrm{C}_{\mathrm{Ad}} \mathrm{H}_{2}\right)$, 1.18-1.42 (m, 4H, $\left.\mathrm{C}_{\mathrm{Ad}} \mathrm{H}_{2}\right), 1.46-1.71\left(\mathrm{~m}, 4 \mathrm{H}, \mathrm{C}_{\mathrm{Ad}} \mathrm{H}_{2}\right), 1.76-1.91\left(\mathrm{~m}, 4 \mathrm{H}, \mathrm{C}_{\mathrm{Ad}} \mathrm{H}_{2}\right), 2.15(\mathrm{~m}$, $\left.1 \mathrm{H}, \mathrm{C}_{\mathrm{Ad}} \mathrm{H}\right), 2.38\left(\mathrm{~s}, 3 \mathrm{H}, \mathrm{CH}_{3}\right), 2.95\left(\mathrm{~s}, 3 \mathrm{H}, \mathrm{CH}_{3} \mathrm{~N}\right), 3.30-3.71\left(\mathrm{~m}, 2 \mathrm{H}, \mathrm{CH}_{2}\right), 3.81-4.12(\mathrm{~m}, 2 \mathrm{H}$, $\left.\mathrm{CH}_{2}\right), 4.13-4.35\left(\mathrm{~m}, 1 \mathrm{H}, \mathrm{CH}_{2}\right), 4.41-4.79\left(\mathrm{~m}, 3 \mathrm{H}, \mathrm{CH}_{2}\right), 7.03\left(\mathrm{~d}, 1 \mathrm{H},{ }^{3} J_{\mathrm{HH}}=8.3 \mathrm{~Hz}, \mathrm{C}_{\mathrm{Ar}} \mathrm{H}\right)$, $7.23\left(\mathrm{~s}, 1 \mathrm{H}, \mathrm{C}_{\mathrm{Ar}} \mathrm{H}\right), 7.58\left(\mathrm{~d}, 1 \mathrm{H},{ }^{3} J_{\mathrm{HH}}=8.3 \mathrm{~Hz}, \mathrm{C}_{\mathrm{Ar}} \mathrm{H}\right), 9.87$ (br. S, $\left.2 \mathrm{H}, \mathrm{NH}\right), 11.26$ (br.s, $1 \mathrm{H}$, $\left.\mathrm{NH}^{+} \mathrm{CH}_{3}\right) .{ }^{13} \mathrm{C}$ NMR $\left(50 \mathrm{MHz}, \mathrm{DMSO}-\mathrm{d}_{6}\right): \delta=19.05\left(\mathrm{CH}_{2}\right), 21.12\left(\mathrm{CH}_{3}\right), 29.13(\mathrm{CH}), 29.66$ $\left(\mathrm{CH}_{3}\right), 32.02(\mathrm{C}), 36.05\left(\mathrm{CH}_{2}\right), 37.70\left(\mathrm{CH}_{2}\right), 39.04\left(\mathrm{CH}_{2}\right), 41.37\left(\mathrm{CH}_{3}\right), 41.52\left(\mathrm{CH}_{2}\right), 43.26$ $\left(\mathrm{CH}_{2}\right), 49.49\left(\mathrm{CH}_{2}\right), 50.05\left(\mathrm{CH}_{2}\right), 57.90(\mathrm{C}), 101.59(\mathrm{C}), 109.59(\mathrm{CH}), 117.43(\mathrm{CH}), 123.35(\mathrm{CH})$, 124.87 (C), 128.42 (C), 130.99 (C), 134.52 (C). Anal. C 67.47, H 8.79, N 8.58\%. Calcd. For $\mathrm{C}_{27} \mathrm{H}_{41} \mathrm{Cl}_{2} \mathrm{~N}_{3}, \mathrm{C} 67.77, \mathrm{H} 8.64, \mathrm{~N} 8.78 \%$.

$N$-(2-(8-Fluoro-2-methyl-3,4-dihydro-1H-pyrido[4,3-b]indol-5(2H)-yl)ethyl)-3,5dimethyladamantane-1-amine dihydrochloride (4c). Brown solid. Yield $31 \%$. Mp 215-216 ${ }^{\circ} \mathrm{C}$. FT IR (KBr $v_{\max }$ in $\left.\mathrm{cm}^{-1}\right): 3425(\mathrm{NH}), 2904\left(\mathrm{CH}_{2}\right), 2848\left(\mathrm{NCH}_{3}\right), 1611(\mathrm{C}=\mathrm{C}), 1455(\mathrm{CH}$ of $\left.\mathrm{CH}_{2}\right) .{ }^{1} \mathrm{H}$ NMR $\left(200 \mathrm{MHz}, \mathrm{DMSO}-\mathrm{d}_{6}\right): \delta=0.85\left(\mathrm{~s}, 6 \mathrm{H}, \mathrm{C}_{\mathrm{Ad}} \mathrm{H}_{3}\right), 1.00-1.21\left(\mathrm{~m}, 2 \mathrm{H}, \mathrm{C}_{\mathrm{Ad}} \mathrm{H}_{2}\right)$, 1.21-1.43 (m, 4H, $\left.\mathrm{C}_{\mathrm{Ad}} \mathrm{H}_{2}\right), 1.43-1.70\left(\mathrm{~m}, 4 \mathrm{H}, \mathrm{C}_{\mathrm{Ad}} \mathrm{H}_{2}\right), 1.70-1.90\left(\mathrm{~m}, 2 \mathrm{H}, \mathrm{C}_{\mathrm{Ad}_{\mathrm{d}}} \mathrm{H}_{2}\right), 2.15(\mathrm{~m}$, $\left.1 \mathrm{H}, \mathrm{C}_{\mathrm{Ad}} \mathrm{H}\right), 2.96\left(\mathrm{~s}, 3 \mathrm{H}, \mathrm{CH}_{3} \mathrm{~N}\right), 3.15-3.37\left(\mathrm{~m}, 2 \mathrm{H}, \mathrm{CH}_{2}\right), 3.38-3.70\left(\mathrm{~m}, 4 \mathrm{H}, \mathrm{CH}_{2}\right), 3.98-4.34$ $\left(\mathrm{m}, 1 \mathrm{H}, \mathrm{CH}_{2}\right), 4.38-4.75\left(\mathrm{~m}, 3 \mathrm{H}, \mathrm{CH}_{2}\right), 7.06\left(\mathrm{t}, 1 \mathrm{H},{ }^{3} \mathrm{~J}_{\mathrm{HF}}={ }^{3} \mathrm{~J}_{\mathrm{HH}}=9.3 \mathrm{~Hz}, \mathrm{C}_{\mathrm{Ar}} \mathrm{H},\right), 7.31(\mathrm{~d}, 1 \mathrm{H}$, $\left.{ }^{3} J_{\mathrm{HH}}=9.9 \mathrm{~Hz}, \mathrm{C}_{\mathrm{Ar}} \mathrm{H},\right), 7.75\left(\mathrm{dd}, 1 \mathrm{H},{ }^{3} J_{\mathrm{HH}}=9.0 \mathrm{~Hz},{ }^{4} J_{\mathrm{HF}}=4.5 \mathrm{~Hz}, \mathrm{C}_{\mathrm{Ar}} \mathrm{H},\right), 9.80(\mathrm{~s}, 2 \mathrm{H}, \mathrm{NH})$, 11.26 (br.s, $\left.1 \mathrm{H}, \mathrm{NH}^{+} \mathrm{CH}_{3}\right) .{ }^{13} \mathrm{C}$ NMR (50 MHz, DMSO-d 6 ): $\delta=19.16\left(\mathrm{CH}_{2}\right), 29.12(\mathrm{CH})$, $29.65\left(\mathrm{CH}_{3}\right), 32.07(\mathrm{C}), 36.04\left(\mathrm{CH}_{2}\right), 37.70\left(\mathrm{CH}_{2}\right), 41.39\left(\mathrm{CH}_{3}\right), 41.51\left(\mathrm{CH}_{2}\right), 43.26\left(\mathrm{CH}_{2}\right)$, $49.45\left(\mathrm{CH}_{2}\right), 49.90\left(\mathrm{CH}_{2}\right), 57.95(\mathrm{C}), 102.30\left(\mathrm{~d},{ }^{4} J_{\mathrm{CF}}=4.4 \mathrm{~Hz}, \mathrm{C}\right), 103.08\left(\mathrm{~d},{ }^{2} J_{\mathrm{CF}}=24.2 \mathrm{~Hz}\right.$, $\mathrm{CH}), 109.66\left(\mathrm{~d},{ }^{2} J_{\mathrm{CF}}=25.6 \mathrm{~Hz}, \mathrm{CH}\right), 110.95\left(\mathrm{~d},{ }^{3} J_{\mathrm{CF}}=9.5 \mathrm{~Hz}, \mathrm{CH}\right), 124.88\left(\mathrm{~d},{ }^{3} J_{\mathrm{CF}}=10.6 \mathrm{~Hz}\right.$, C), $132.75(\mathrm{C}), 133.07$ (C), $157.25\left(\mathrm{~d},{ }^{1} J_{\mathrm{CF}}=233.1 \mathrm{~Hz}, \mathrm{CF}\right) .{ }^{19} \mathrm{~F}$ NMR $\left(188 \mathrm{MHz}, \mathrm{DMSO}-\mathrm{d}_{6}\right)$ : $\delta=-124.4\left(\mathrm{td}, 1 \mathrm{~F},{ }^{3} J_{\mathrm{FH}}=9.2 \mathrm{~Hz},{ }^{4} J_{\mathrm{FH}}=4.6 \mathrm{~Hz}, \mathrm{C}_{\mathrm{Ar}} \mathrm{F}\right)$. Anal. C 64.61, H 7.88, N 8.79\%. Calcd. For $\mathrm{C}_{26} \mathrm{H}_{38} \mathrm{Cl}_{2} \mathrm{FN}_{3}, \mathrm{C} 64.72, \mathrm{H} 7.94, \mathrm{~N} 8.71 \%$.

$\mathrm{N}$-(2-(2-Methyl-3,4-dihydro-1H-pyrido[4,3-b]indol-5(2H)-yl)ethyl)adamantane-1-amine dihydrochloride (4d). Pale brown solid. Yield 52\%. Mp 160-162 ${ }^{\circ} \mathrm{C}$. FT IR ( $\mathrm{KBr} v_{\max }$ in $\left.\mathrm{cm}^{-1}\right)$ : $3421(\mathrm{NH}), 2906\left(\mathrm{CH}_{2}\right), 2852\left(\mathrm{NCH}_{3}\right), 1614(\mathrm{C}=\mathrm{C}), 1454\left(\mathrm{CH}\right.$ of $\left.\mathrm{CH}_{2}\right) . \mathrm{H}$ NMR $\left(200 \mathrm{MHz}, \mathrm{DMSO}-\mathrm{d}_{6}\right): \delta=1.37-1.68\left(\mathrm{~m}, 6 \mathrm{H}, \mathrm{C}_{\mathrm{Ad}} \mathrm{H}_{2}\right), 1.68-1.82\left(\mathrm{~m}, 3 \mathrm{H}, \mathrm{C}_{\mathrm{Ad}} \mathrm{H}_{2}\right), 1.82-1.96$ $\left(\mathrm{m}, 3 \mathrm{H}, \mathrm{C}_{\mathrm{Ad}} \mathrm{H}_{2}\right), 1.97-2.14\left(\mathrm{~m}, 3 \mathrm{H}, \mathrm{C}_{\mathrm{Ad}} \mathrm{H}\right), 2.98\left(\mathrm{~d}, 3 \mathrm{H},{ }^{3} \mathrm{~J}_{\mathrm{HH}}=4.4 \mathrm{~Hz}, \mathrm{CH}_{3} \mathrm{~N}\right), 3.15-3.37$ $\left(\mathrm{m}, 3 \mathrm{H}, \mathrm{CH}_{2}\right), 3.38-3.58\left(\mathrm{~m}, 1 \mathrm{H}, \mathrm{CH}_{2}\right), 3.74-3.96\left(\mathrm{~m}, 1 \mathrm{H}, \mathrm{CH}_{2}\right), 3.82-4.14\left(\mathrm{~m}, 2 \mathrm{H}, \mathrm{CH}_{2}\right)$, $4.27-4.48\left(\mathrm{~m}, 1 \mathrm{H}, \mathrm{CH}_{2}\right), 4.54-4.84\left(\mathrm{~m}, 2 \mathrm{H}, \mathrm{CH}_{2}\right), 7.39\left(\mathrm{dd}, 1 \mathrm{H},{ }^{3} \mathrm{~J}_{\mathrm{HH}}=8.4 \mathrm{~Hz},{ }^{3} J_{\mathrm{HH}}=7.9 \mathrm{~Hz}\right.$, $\left.\mathrm{C}_{\mathrm{Ar}} \mathrm{H}\right), 7.52\left(\mathrm{dd}, 1 \mathrm{H},{ }^{3} J_{\mathrm{HH}}=8.4 \mathrm{~Hz},{ }^{3} J_{\mathrm{HH}}=7.9 \mathrm{~Hz}, \mathrm{C}_{\mathrm{Ar}} \mathrm{H}\right), 7.78\left(\mathrm{~d}, 1 \mathrm{H},{ }^{3} J_{\mathrm{HH}}=7.9 \mathrm{~Hz}, \mathrm{C}_{\mathrm{Ar}} \mathrm{H}\right)$, $7.97\left(\mathrm{~d}, 1 \mathrm{H},{ }^{3} J_{\mathrm{HH}}=8.4 \mathrm{~Hz}, \mathrm{C}_{\mathrm{Ar}} \mathrm{H}\right), 8.29$ (br. S, $\left.2 \mathrm{H}, \mathrm{NH}\right), 11.44$ (br.s, $\left.1 \mathrm{H}, \mathrm{NH}^{+} \mathrm{CH}_{3}\right) .{ }^{13} \mathrm{C} \mathrm{NMR}$ (50 MHz, DMSO): $\delta=18.93\left(\mathrm{CH}_{2}\right), 28.21(\mathrm{CH}), 28.34\left(\mathrm{CH}_{2}\right), 35.04\left(\mathrm{CH}_{2}\right), 37.44\left(\mathrm{CH}_{2}\right), 41.24$ $\left(\mathrm{CH}_{3}\right), 49.32\left(\mathrm{CH}_{2}\right), 49.88\left(\mathrm{CH}_{2}\right), 50.84(\mathrm{C}), 102.04(\mathrm{C}), 109.74(\mathrm{CH}), 117.68(\mathrm{CH}), 119.63(\mathrm{CH})$, $121.87(\mathrm{CH}), 124.55$ (C), 130.96 (C), 136.01 (C). Anal. C 66.22, H 8.19, N 9.45\%. Calcd. For $\mathrm{C}_{24} \mathrm{H}_{35} \mathrm{Cl}_{2} \mathrm{~N}_{3}, \mathrm{C} 66.04, \mathrm{H} 8.08, \mathrm{~N}$ 9.63\%.

$\mathrm{N}$-(2-(2,8-Dimethyl-3,4-dihydro-1H-pyrido[4,3-b]indol-5(2H)-yl)ethyl)adamantane-1amine dihydrochloride (4e). Brown solid. Yield $43 \%$. Mp $148-150{ }^{\circ} \mathrm{C}$. FT IR (KBr $v_{\max }$ in $\left.\mathrm{cm}^{-1}\right)$ : $3412(\mathrm{NH}), 2914\left(\mathrm{CH}_{2}\right), 2854\left(\mathrm{NCH}_{3}\right), 1618(\mathrm{C}=\mathrm{C}), 1464\left(\mathrm{CH}\right.$ of $\left.\mathrm{CH}_{2}\right) .{ }^{1} \mathrm{H}$ NMR 
(200 MHz, DMSO-d 6 ): $\delta=1.39-1.71\left(\mathrm{~m}, 6 \mathrm{H}, \mathrm{C}_{\mathrm{Ad}} \mathrm{H}_{2}\right), 1.71-1.85\left(\mathrm{~m}, 3 \mathrm{H}, \mathrm{C}_{\mathrm{Ad}_{2}} \mathrm{H}_{2}\right), 1.85-1.98$ $\left(\mathrm{m}, 3 \mathrm{H}, \mathrm{C}_{\mathrm{Ad}} \mathrm{H}_{2}\right), 1.98-2.16\left(\mathrm{~m}, 3 \mathrm{H}, \mathrm{C}_{\mathrm{Ad}} \mathrm{H}\right), 2.34\left(\mathrm{~s}, 3 \mathrm{H}, \mathrm{CH}_{3}\right), 2.93\left(\mathrm{~s}, 3 \mathrm{H}, \mathrm{CH}_{3} \mathrm{~N}\right), 3.10-3.30$ $\left(\mathrm{m}, 3 \mathrm{H}, \mathrm{CH}_{2}\right), 3.37-3.58\left(\mathrm{~m}, 1 \mathrm{H}, \mathrm{CH}_{2}\right), 3.61-3.79\left(\mathrm{~m}, 1 \mathrm{H}, \mathrm{CH}_{2}\right), 3.82-4.14\left(\mathrm{~m}, 2 \mathrm{H}, \mathrm{CH}_{2}\right)$, 4.14-4.34 (m, 1H, $\left.\mathrm{CH}_{2}\right), 4.41-4.70\left(\mathrm{~m}, 2 \mathrm{H}, \mathrm{CH}_{2}\right), 6.99\left(\mathrm{~d}, 1 \mathrm{H},{ }^{3} J_{\mathrm{HH}}=8.6 \mathrm{~Hz}, \mathrm{C}\right.$ Ar $\left.\mathrm{H}\right), 7.20$ $\left(\mathrm{s}, 1 \mathrm{H}, \mathrm{C}_{\mathrm{Ar}} \mathrm{H}\right), 7.56\left(\mathrm{~d}, 1 \mathrm{H},{ }^{3} J_{\mathrm{HH}}=8.6 \mathrm{~Hz}, \mathrm{C}_{\mathrm{Ar}} \mathrm{H}\right), 8.22$ (br. S, 2H, NH), 11.34 (br.s, 1H, $\left.\mathrm{NH}^{+} \mathrm{CH}_{3}\right) .{ }^{13} \mathrm{C}$ NMR $\left(50 \mathrm{MHz}, \mathrm{DMSO}-\mathrm{d}_{6}\right): \delta=19.56\left(\mathrm{CH}_{2}\right), 21.60\left(\mathrm{CH}_{3}\right), 28.82(\mathrm{CH}), 28.94$ $\left(\mathrm{CH}_{2}\right), 35.65\left(\mathrm{CH}_{2}\right), 37.93\left(\mathrm{CH}_{2}\right), 41.35\left(\mathrm{CH}_{3}\right), 49.95\left(\mathrm{CH}_{2}\right), 50.50\left(\mathrm{CH}_{2}\right), 51.45(\mathrm{C}), 102.13(\mathrm{C})$, $110.04(\mathrm{CH}), 117.92(\mathrm{CH}), 123.78(\mathrm{CH}), 125.38(\mathrm{C}), 128.90(\mathrm{C}), 131.49(\mathrm{C}), 135.02(\mathrm{C})$. Anal. C 66.51, $\mathrm{H}$ 8.47, N 9.46\%. Calcd. For $\mathrm{C}_{25} \mathrm{H}_{37} \mathrm{Cl}_{2} \mathrm{~N}_{3}, \mathrm{C} 66.65, \mathrm{H}$ 8.28, N 9.33.

$\mathrm{N}$-(2-(8-Fluoro-2-methyl-3,4-dihydro-1H-pyrido[4,3- $b$ ]indol-5(2H)-yl)ethyl)adamantane-1amine dihydrochloride (4f). Brown solid. Yield $32 \%$. Mp $214-215^{\circ} \mathrm{C}$. FT IR ( $\mathrm{KBr} v_{\max }$ in $\left.\mathrm{cm}^{-1}\right)$ : $3434(\mathrm{NH}), 2904\left(\mathrm{CH}_{2}\right), 2846\left(\mathrm{NCH}_{3}\right), 1610(\mathrm{C}=\mathrm{C}), 1452\left(\mathrm{CH}\right.$ of $\left.\mathrm{CH}_{2}\right) .{ }^{1} \mathrm{H}$ NMR $\left(200 \mathrm{MHz}, \mathrm{DMSO}-\mathrm{d}_{6}\right): \delta=1.42-1.72\left(\mathrm{~m}, 6 \mathrm{H}, \mathrm{C}_{\mathrm{Ad}} \mathrm{H}_{2}\right), 1.79$ (br.s, $\left.2 \mathrm{H}, \mathrm{C}_{\mathrm{Ad}} \mathrm{H}_{2}\right), 1.79$ (br.s, $4 \mathrm{H}$, $\left.\mathrm{C}_{\mathrm{Ad}} \mathrm{H}_{2}\right), 2.05\left(\mathrm{~s}, 3 \mathrm{H}, \mathrm{C}_{\mathrm{Ad}} \mathrm{H}\right), 2.94\left(\mathrm{~s}, 3 \mathrm{H}, \mathrm{NCH}_{3}\right), 2.96-3.29\left(\mathrm{~m}, 4 \mathrm{H}, \mathrm{CH}_{2}\right), 3.26-3.78(\mathrm{~m}, 3 \mathrm{H}$, $\left.\mathrm{CH}_{2}\right), 4.14-4.34\left(\mathrm{~m}, 1 \mathrm{H}, \mathrm{CH}_{2}\right), 4.45-4.69\left(\mathrm{~m}, 2 \mathrm{H}, \mathrm{CH}_{2}\right), 7.05\left(\mathrm{t}, 1 \mathrm{H},{ }^{3} \mathrm{~J}_{\mathrm{HF}}={ }^{3} \mathrm{~J}_{\mathrm{HH}}=9.0 \mathrm{~Hz}\right.$, $\left.\mathrm{C}_{\mathrm{Ar}} \mathrm{H}\right), 7.29\left(\mathrm{~d}, 1 \mathrm{H},{ }^{3} J_{\mathrm{HH}}=9.0 \mathrm{~Hz},{ }^{4} J_{\mathrm{HH}}=2.3 \mathrm{~Hz}, \mathrm{C}_{\mathrm{Ar}} \mathrm{H}\right), 7.75\left(\mathrm{dd}, 1 \mathrm{H},{ }^{3} J_{\mathrm{HH}}=9.0 \mathrm{~Hz}\right.$, $\left.{ }^{4} J_{\mathrm{HF}}=4.5 \mathrm{~Hz}, \mathrm{C}_{\mathrm{Ar}} \mathrm{H}\right), 8.17$ (s, 2H, NH), 11.23 (br.s, $\left.1 \mathrm{H}, \mathrm{NH}^{+} \mathrm{CH}_{3}\right) .{ }^{13} \mathrm{C} \mathrm{NMR}(50 \mathrm{MHz}$, DMSO-d $\left.)_{6}\right): \delta=19.10\left(\mathrm{CH}_{2}\right), 28.30(\mathrm{CH}), 28.43(\mathrm{CH}), 35.13\left(\mathrm{CH}_{2}\right), 35.21\left(\mathrm{CH}_{2}\right), 37.47\left(\mathrm{CH}_{2}\right)$, $39.65\left(\mathrm{CH}_{2}\right), 41.30\left(\mathrm{CH}_{3}\right), 49.29\left(\mathrm{CH}_{2}\right), 49.43\left(\mathrm{CH}_{2}\right), 50.92(\mathrm{C}), 102.33\left(\mathrm{~d},{ }^{4} J_{\mathrm{CF}}=4.4 \mathrm{~Hz}, \mathrm{C}\right)$, $102.13\left(\mathrm{~d},{ }^{2} J_{\mathrm{CF}}=24.2 \mathrm{~Hz}, \mathrm{CH}\right), 109.71\left(\mathrm{~d},{ }^{2} J_{\mathrm{CF}}=26.0 \mathrm{~Hz}, \mathrm{CH}\right), 110.98\left(\mathrm{~d},{ }^{3} J_{\mathrm{CF}}=9.5 \mathrm{~Hz}, \mathrm{CH}\right)$, $124.94\left(\mathrm{~d},{ }^{3} J_{\mathrm{CF}}=10.6 \mathrm{~Hz}, \mathrm{C}\right), 132.79(\mathrm{C}), 133.13(\mathrm{C}), 157.29\left(\mathrm{~d},{ }^{1} J_{\mathrm{CF}}=233.1 \mathrm{~Hz}, \mathrm{CF}\right) .{ }^{19} \mathrm{~F}$ NMR $\left(188 \mathrm{MHz}, \mathrm{DMSO}-\mathrm{d}_{6}\right): \delta=-124.8\left(\mathrm{td}, 1 \mathrm{~F},{ }^{3} J_{\mathrm{FH}}=9.2 \mathrm{~Hz},{ }^{4} J_{\mathrm{FH}}=4.6 \mathrm{~Hz}, \mathrm{CF}\right)$. Anal. C 63.57, $\mathrm{H} 7.43, \mathrm{~N} 9.14 \%$. Calcd. For $\mathrm{C}_{24} \mathrm{H}_{34} \mathrm{Cl}_{2} \mathrm{FN}_{3}, \mathrm{C} 63.43, \mathrm{H} 7.54, \mathrm{~N} 9.25 \%$.

\subsubsection{General Procedure for the Preparation of Compounds 8a-f}

A mixture of carboline $5 \mathrm{a}-\mathrm{c}(1 \mathrm{mmol})$, chloroacetamide 6 (1 mmol) and $\mathrm{KOH}(1.1 \mathrm{mmol})$ in DMF $(10 \mathrm{~mL})$ was stirred at $20{ }^{\circ} \mathrm{C}$ for $3 \mathrm{~h}$. The reaction mixture was poured into water $(50 \mathrm{~mL})$. The resulting solid was filtered off, dried and dissolved in acetone $(10 \mathrm{~mL})$. A $37 \%$ $(v / v)$ aqueous $\mathrm{HCl}(0.2 \mathrm{~mL})$ was added to this solution and the precipitate that formed was filtered off and dried.

3,5-Dimethyladamantan-1-yl)-2-(2-methyl-3,4-dihydro- $1 H$-pyrido[4,3- $b]$ indol-5(2H)yl)acetamide hydrochloride (8a). White solid. Yield 63\%, mp 257-259 ${ }^{\circ} \mathrm{C}$. FT IR (KBr $v_{\text {max }}$ in $\left.\mathrm{cm}^{-1}\right)$ : $3410(\mathrm{NH}), 3260(\mathrm{CONH}), 2904\left(\mathrm{CH}_{2}\right), 2852\left(\mathrm{NCH}_{3}\right), 1676(\mathrm{C}=\mathrm{O}), 1542(\mathrm{NH}$ of amide), $1455\left(\mathrm{CH}\right.$ of $\left.\mathrm{CH}_{2}\right) .{ }^{1} \mathrm{H} \mathrm{NMR}\left(200 \mathrm{MHz}, \mathrm{DMSO}-\mathrm{d}_{6}\right): \delta=0.85\left(\mathrm{~s}, 6 \mathrm{H}, \mathrm{C}_{\mathrm{Ad}_{3}} \mathrm{H}_{3}\right)$,

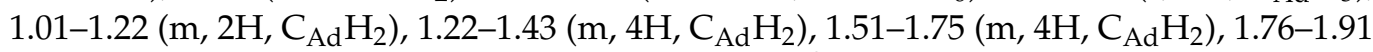
$\left(\mathrm{m}, 2 \mathrm{H}, \mathrm{C}_{\mathrm{Ad}} \mathrm{H}_{2}\right), 2.16$ (br.s, $\left.1 \mathrm{H}, \mathrm{C}_{\mathrm{Ad}} \mathrm{H}\right), 2.96\left(\mathrm{~d}, 3 \mathrm{H},{ }^{3} \mathrm{~J}_{\mathrm{HH}}=4.0 \mathrm{~Hz}, \mathrm{CH}_{3} \mathrm{~N}\right), 3.05-3.30(\mathrm{~m}$, 2H, $\left.\mathrm{CH}_{2}\right), 3.30-3.80\left(\mathrm{~m}, 2 \mathrm{H}, \mathrm{CH}_{2}\right), 4.06-4.60\left(\mathrm{~m}, 2 \mathrm{H}, \mathrm{CH}_{2}\right), 4.75\left(\mathrm{~s}, 2 \mathrm{H}, \mathrm{CH}_{2}\right), 6.90-7.26(\mathrm{~m}$, $\left.2 \mathrm{H}, \mathrm{CH}_{\mathrm{Ar}}\right), 7.28-7.62\left(\mathrm{~m}, 2 \mathrm{H}, \mathrm{CH}_{\mathrm{Ar}}\right), 8.21(\mathrm{~s}, 1 \mathrm{H}, \mathrm{NH}), 11.38$ (br.s, $\left.1 \mathrm{H}, \mathrm{NH}^{+} \mathrm{CH}_{3}\right) .{ }^{13} \mathrm{C} \mathrm{NMR}$ $\left(50 \mathrm{MHz}, \mathrm{DMSO}-\mathrm{d}_{6}\right): \delta=19.26\left(\mathrm{CH}_{2}\right), 29.45(\mathrm{CH}), 30.03\left(\mathrm{CH}_{3}\right), 31.80(\mathrm{C}), 39.41\left(\mathrm{CH}_{2}\right), 41.44$ $\left(\mathrm{CH}_{2}\right), 42.22\left(\mathrm{CH}_{3}\right), 45.99\left(\mathrm{CH}_{2}\right), 46.85\left(\mathrm{CH}_{2}\right), 49.44\left(\mathrm{CH}_{2}\right), 49.95\left(\mathrm{CH}_{2}\right), 50.16\left(\mathrm{CH}_{2}\right), 52.70$ (C), $103.33(\mathrm{C}), 109.68(\mathrm{CH}), 117.43(\mathrm{CH}), 119.29(\mathrm{CH}), 121.37(\mathrm{CH}), 124.33(\mathrm{CH}), 131.95(\mathrm{C})$, $136.86(\mathrm{C}), 166.31(\mathrm{C}=\mathrm{O})$. Anal. C 70.45, $\mathrm{H}$ 8.12, $\mathrm{N}$ 9.27\%. Calcd. For $\mathrm{C}_{26} \mathrm{H}_{36} \mathrm{ClN}_{3} \mathrm{O}, \mathrm{C} 70.65$, H 8.21, N 9.51\%.

2-(2,8-Dimethyl-3,4-dihydro-1H-pyrido[4,3-b]indol-5(2H)-yl)-N-(3,5-dimethyladamantan1-yl)acetamide hydrochloride (8b). White solid. Yield 54\%. Mp 205-208 ${ }^{\circ} \mathrm{C}$. FT IR (KBr $v_{\max }$ in $\left.\mathrm{cm}^{-1}\right): 3421(\mathrm{NH}), 3254(\mathrm{CONH}), 2902\left(\mathrm{CH}_{2}\right), 2861\left(\mathrm{NCH}_{3}\right), 1678(\mathrm{C}=\mathrm{O}), 1543(\mathrm{NH}$ of amide), $1466\left(\mathrm{CH}\right.$ of $\left.\mathrm{CH}_{2}\right) .{ }^{1} \mathrm{H}$ NMR $\left(200 \mathrm{MHz}, \mathrm{DMSO}-\mathrm{d}_{6}\right): \delta=0.77\left(\mathrm{~s}, 6 \mathrm{H}, \mathrm{C}_{\mathrm{Ad}} \mathrm{H}_{3}\right)$, 1.00-1.12 (m, 2H, $\left.\mathrm{C}_{\mathrm{Ad}} \mathrm{H}_{2}\right), 1.12-1.39\left(\mathrm{~m}, 4 \mathrm{H}, \mathrm{C}_{\mathrm{Ad}_{2}} \mathrm{H}_{2}\right), 1.44-1.66\left(\mathrm{~m}, 4 \mathrm{H}, \mathrm{C}_{\mathrm{Ad}_{2}} \mathrm{H}_{2}\right), 1.66-1.84$ $\left(\mathrm{m}, 2 \mathrm{H}, \mathrm{C}_{\mathrm{Ad}} \mathrm{H}_{2}\right), 2.04$ (br.s, $\left.1 \mathrm{H}, \mathrm{C}_{\mathrm{Ad}} \mathrm{H}\right), 2.35\left(\mathrm{~s}, 3 \mathrm{H}, \mathrm{CH}_{3}\right), 2.89\left(\mathrm{~s}, 3 \mathrm{H}, \mathrm{CH}_{3} \mathrm{~N}\right), 2.98-3.24(\mathrm{~m}$, $\left.2 \mathrm{H}, \mathrm{CH}_{2}\right), 3.36-3.78\left(\mathrm{~m}, 2 \mathrm{H}, \mathrm{CH}_{2}\right), 4.08-4.59\left(\mathrm{~m}, 2 \mathrm{H}, \mathrm{CH}_{2}\right), 4.68\left(\mathrm{~s}, 2 \mathrm{H}, \mathrm{CH}_{2}\right), 6.95(\mathrm{~d}, 1 \mathrm{H}$, $\left.{ }^{3} J_{\mathrm{HH}}=8.1 \mathrm{~Hz}, \mathrm{C}_{\mathrm{Ar}} \mathrm{H}\right), 7.18\left(\mathrm{~s}, 1 \mathrm{H}, \mathrm{C}_{\mathrm{Ar}} \mathrm{H}\right), 7.31\left(\mathrm{~d}, 1 \mathrm{H},{ }^{3} J_{\mathrm{HH}}=8.1 \mathrm{~Hz}, \mathrm{C}_{\mathrm{Ar}} \mathrm{H}\right), 8.06(\mathrm{~s}, 1 \mathrm{H}$, $\mathrm{NH}), 11.18$ (br.s, $\left.1 \mathrm{H}, \mathrm{NH}^{+} \mathrm{CH}_{3}\right) .{ }^{13} \mathrm{C} \mathrm{NMR}\left(50 \mathrm{MHz}, \mathrm{DMSO}-\mathrm{d}_{6}\right): \delta=19.24\left(\mathrm{CH}_{2}\right), 21.10$ $\left(\mathrm{CH}_{3}\right), 29.43(\mathrm{CH}), 30.01\left(\mathrm{CH}_{3}\right), 31.80(\mathrm{C}), 39.40\left(\mathrm{CH}_{2}\right), 41.46\left(\mathrm{CH}_{3}\right), 42.20\left(\mathrm{CH}_{2}\right), 46.04$ $\left(\mathrm{CH}_{2}\right), 46.86\left(\mathrm{CH}_{2}\right), 49.54\left(\mathrm{CH}_{2}\right), 50.06\left(\mathrm{CH}_{2}\right), 50.14\left(\mathrm{CH}_{2}\right), 52.67(\mathrm{C}), 100.82(\mathrm{C}), 109.34(\mathrm{CH})$, 
$117.12(\mathrm{CH}), 122.85(\mathrm{CH}), 124.54(\mathrm{C}), 127.91(\mathrm{C}), 131.90(\mathrm{C}), 135.30(\mathrm{C}), 166.32(\mathrm{C}=\mathrm{O})$. Anal. C 71.23, H 8.24, N 9.29\%. Calcd. For $\mathrm{C}_{27} \mathrm{H}_{38} \mathrm{ClN}_{3} \mathrm{O}, \mathrm{C} 71.11, \mathrm{H} 8.40, \mathrm{~N} 9.21 \%$.

$\mathrm{N}$-(3,5-Dimethyladamantan-1-yl)-2-(8-fluoro-2-methyl-3,4-dihydro-1 $H$-pyrido[4,3-b] indol$5(2 \mathrm{H})$-yl)acetamide hydrochloride (8c). White solid. Yield $68 \%$. Mp $256-258^{\circ} \mathrm{C}$. FT IR $(\mathrm{KBr}$ $v_{\max }$ in $\left.\mathrm{cm}^{-1}\right)$ : $3447(\mathrm{NH}), 3274(\mathrm{CONH}), 2898\left(\mathrm{CH}_{2}\right), 2841\left(\mathrm{NCH}_{3}\right), 1677(\mathrm{C}=\mathrm{O}), 1545(\mathrm{NH}$ of amide), $1453\left(\mathrm{CH}\right.$ of $\left.\mathrm{CH}_{2}\right) .{ }^{1} \mathrm{H}$ NMR $\left(200 \mathrm{MHz}, \mathrm{DMSO}-\mathrm{d}_{6}\right): \delta=0.80\left(\mathrm{~s}, 6 \mathrm{H}, \mathrm{C}_{\mathrm{Ad}} \mathrm{H}_{3}\right)$, 1.00-1.15 (m, 2H, $\left.\mathrm{C}_{\mathrm{Ad}} \mathrm{H}_{2}\right), 1.15-1.40\left(\mathrm{~m}, 4 \mathrm{H}, \mathrm{C}_{\mathrm{Ad}} \mathrm{H}_{2}\right), 1.46-1.69\left(\mathrm{~m}, 4 \mathrm{H}, \mathrm{C}_{\mathrm{Ad}} \mathrm{H}_{2}\right), 1.69-1.87$ $\left(\mathrm{m}, 2 \mathrm{H}, \mathrm{C}_{\mathrm{Ad}} \mathrm{H}_{2}\right), 1.97-2.20\left(\mathrm{~m}, 1 \mathrm{H}, \mathrm{C}_{\mathrm{Ad}} \mathrm{H}\right), 2.96\left(\mathrm{~d}, 3 \mathrm{H},{ }^{3} \mathrm{~J}_{\mathrm{HH}}=4.0 \mathrm{~Hz}, \mathrm{CH}_{3} \mathrm{~N}\right), 3.05-3.30(\mathrm{~m}$, $\left.2 \mathrm{H}, \mathrm{CH}_{2}\right), 3.36-3.60\left(\mathrm{~m}, 2 \mathrm{H}, \mathrm{CH}_{2}\right), 4.25\left(\mathrm{dd}, 1 \mathrm{H},{ }^{2} J_{\mathrm{HH}}=13.4 \mathrm{~Hz},{ }^{3} J_{\mathrm{HH}}=6.3 \mathrm{~Hz}, \mathrm{CH}_{2}\right), 4.58(\mathrm{~d}$, $\left.1 \mathrm{H},{ }^{2} J_{\mathrm{HH}}=13.4 \mathrm{~Hz}, \mathrm{CH}_{2}\right), 4.75\left(\mathrm{~s}, 2 \mathrm{H}, \mathrm{CH}_{2}\right), 7.01\left(\mathrm{td}, 1 \mathrm{H},{ }^{3} J_{\mathrm{HF}}={ }^{3} J_{\mathrm{HH}}=9.3 \mathrm{~Hz},{ }^{4} J_{\mathrm{HH}}=2.3\right.$ $\left.\mathrm{C}_{\mathrm{Ar}} \mathrm{H}\right), 7.26\left(\mathrm{dd}, 1 \mathrm{H},{ }^{3} J_{\mathrm{HH}}=9.9 \mathrm{~Hz},{ }^{4} J_{\mathrm{HH}}=2.3 \mathrm{~Hz}, \mathrm{C}_{\mathrm{Ar}} \mathrm{H},\right), 7.45\left(\mathrm{dd}, 1 \mathrm{H},{ }^{3} J_{\mathrm{HH}}=9.0 \mathrm{~Hz}\right.$, ${ }^{4} J_{\mathrm{HF}}=4.5 \mathrm{~Hz}, \mathrm{C}_{\mathrm{Ar}} \mathrm{H}$ ), 8.07 (s, 1H, NH), 10.82 (br.s, $\left.1 \mathrm{H}, \mathrm{NH}^{+} \mathrm{CH}_{3}\right) .{ }^{13} \mathrm{C} \mathrm{NMR}(50 \mathrm{MHz}$, DMSO-d $\left.\mathrm{d}_{6}\right): \delta=19.28\left(\mathrm{CH}_{2}\right), 29.33(\mathrm{CH}), 29.91\left(\mathrm{CH}_{3}\right), 31.70(\mathrm{C}), 39.29\left(\mathrm{CH}_{2}\right), 41.37\left(\mathrm{CH}_{3}\right)$, $42.10\left(\mathrm{CH}_{2}\right), 46.10\left(\mathrm{CH}_{2}\right), 46.74\left(\mathrm{CH}_{2}\right), 49.25\left(\mathrm{CH}_{2}\right), 49.78\left(\mathrm{CH}_{2}\right), 50.04\left(\mathrm{CH}_{2}\right), 52.63(\mathrm{C})$, $101.54\left(\mathrm{~d},{ }^{4} J_{\mathrm{CF}}=4.4 \mathrm{~Hz}, \mathrm{C}\right), 102.60\left(\mathrm{~d},{ }^{2} J_{\mathrm{CF}}=23.8 \mathrm{~Hz}, \mathrm{CH}\right), 109.09\left(\mathrm{~d},{ }^{2} J_{\mathrm{CF}}=26.0 \mathrm{~Hz}, \mathrm{CH}\right)$, $110.63\left(\mathrm{~d},{ }^{3} J_{\mathrm{CF}}=9.1 \mathrm{~Hz}, \mathrm{CH}\right), 124.44\left(\mathrm{~d},{ }^{3} J_{\mathrm{CF}}=10.2 \mathrm{~Hz}, \mathrm{C}\right), 133.48(\mathrm{C}), 133.91(\mathrm{C}), 156.97$ $\left(\mathrm{d},{ }^{1} J_{\mathrm{CF}}=232.4 \mathrm{~Hz}, \mathrm{CF}\right), 166.03(\mathrm{C}=\mathrm{O}) .{ }^{19} \mathrm{~F}$ NMR $\left(188 \mathrm{MHz}, \mathrm{DMSO}_{\mathrm{d}}\right): \delta=-126.2(\mathrm{td}, 1 \mathrm{~F}$, $\left.{ }^{3} J_{\mathrm{FH}}=9.2 \mathrm{~Hz},{ }^{4} \mathrm{~J}_{\mathrm{FH}}=4.6 \mathrm{~Hz}, \mathrm{CF}\right)$. Anal. C 67.73, H 7.44, N 9.24\%. Calcd. For $\mathrm{C}_{26} \mathrm{H}_{35} \mathrm{ClFN}_{3} \mathrm{O}$, C 67.88, H 7.67, N 9.13\%.

N-(Adamantan-1-yl)-2-(2-methyl-3,4-dihydro-1H-pyrido[4,3-b]indol-5(2H)-yl)acetamide hydrochloride (8d). Grey solid. Yield 64\%. Mp 246-248 ${ }^{\circ} \mathrm{C}$. FT IR $\left(\mathrm{KBr} \gamma_{\max }\right.$ in $\left.\mathrm{cm}^{-1}\right)$ : $3376(\mathrm{NH}), 3256(\mathrm{CONH}), 2908\left(\mathrm{CH}_{2}\right), 2849\left(\mathrm{NCH}_{3}\right), 1679(\mathrm{C}=\mathrm{O}), 1542(\mathrm{NH}$ of amide), $1466\left(\mathrm{CH}\right.$ of $\left.\mathrm{CH}_{2}\right) .{ }^{1} \mathrm{H}$ NMR $\left(200 \mathrm{MHz}, \mathrm{DMSO}-\mathrm{d}_{6}\right): \delta=1.58$ (br.s, $\left.6 \mathrm{H}, \mathrm{C}_{\mathrm{Ad}} \mathrm{H}_{2}\right), 1.92$ (br.s, $\left.6 \mathrm{H}, \mathrm{C}_{\mathrm{Ad}} \mathrm{H}_{2}\right), 1.96$ (br.s, $\left.3 \mathrm{H}, \mathrm{C}_{\mathrm{Ad}} \mathrm{H}\right), 2.89\left(\mathrm{~d}, 3 \mathrm{H},{ }^{3} \mathrm{~J}_{\mathrm{HH}}=3.5 \mathrm{~Hz}, \mathrm{NCH}_{3}\right), 2.96-3.28(\mathrm{~m}, 2 \mathrm{H}$, $\left.\mathrm{CH}_{2}\right), 3.28-3.78\left(\mathrm{~m}, 2 \mathrm{H}, \mathrm{CH}_{2}\right), 4.23\left(\mathrm{dd}, 1 \mathrm{H},{ }^{2} J_{\mathrm{HH}}=14.0 \mathrm{~Hz},{ }^{3} J_{\mathrm{HH}}=6.3 \mathrm{~Hz}, \mathrm{CH}_{2}\right), 4.05(\mathrm{~d}$, $\left.1 \mathrm{H},{ }^{2} J_{\mathrm{HH}}=14.0 \mathrm{~Hz}, \mathrm{CH}_{2}\right), 4.74\left(\mathrm{~s}, 2 \mathrm{H}, \mathrm{CH}_{2} \mathrm{C}(\mathrm{O})\right), 6.95-7.21\left(\mathrm{~m}, 2 \mathrm{H}, \mathrm{CH}_{\mathrm{Ar}}\right), 7.33-7.55(\mathrm{~m}$, $\left.2 \mathrm{H}, \mathrm{CH}_{\mathrm{Ar}}\right), 8.11(\mathrm{~s}, 1 \mathrm{H}, \mathrm{NH}), 11.28$ (br.s, $\left.1 \mathrm{H}, \mathrm{NH}^{+} \mathrm{CH}_{3}\right) .{ }^{13} \mathrm{C} \mathrm{NMR}\left(50 \mathrm{MHz}, \mathrm{DMSO}-\mathrm{d}_{6}\right)$ : $\delta=19.25\left(\mathrm{CH}_{2}\right), 28.75(\mathrm{CH}), 35.94\left(\mathrm{CH}_{2}\right), 40.90\left(\mathrm{CH}_{2}\right), 41.47\left(\mathrm{CH}_{3}\right), 46.02\left(\mathrm{CH}_{2}\right), 49.49\left(\mathrm{CH}_{2}\right)$, $49.99\left(\mathrm{CH}_{2}\right), 51.15(\mathrm{C}), 101.38(\mathrm{C}), 109.68(\mathrm{CH}), 117.44(\mathrm{CH}), 119.30(\mathrm{CH}), 121.38(\mathrm{CH}), 124.33$ (C), $131.95(\mathrm{C}), 136.90(\mathrm{C}), 166.23(\mathrm{C}=\mathrm{O})$. Anal. C 69.52, H 7.63, N 10.23\%. Calcd. For $\mathrm{C}_{24} \mathrm{H}_{32} \mathrm{ClN}_{3} \mathrm{O}, \mathrm{C} 69.63, \mathrm{H} 7.79, \mathrm{~N} 10.15 \%$.

$\mathrm{N}$-(Adamantan-1-yl)-2-(2,8-dimethyl-3,4-dihydro-1H-pyrido[4,3-b]indol-5(2H)-yl)acetamide hydrochloride (8e). Pale brown solid. Yield $72 \%$. Mp 260-262 ${ }^{\circ} \mathrm{C}$. FT IR $\left(\mathrm{KBr} v_{\max }\right.$ in $\left.\mathrm{cm}^{-1}\right)$ : $3425(\mathrm{NH}), 3271(\mathrm{CONH}), 2907\left(\mathrm{CH}_{2}\right), 2850\left(\mathrm{NCH}_{3}\right), 1675(\mathrm{C}=\mathrm{O}), 1542(\mathrm{NH}$ of amide), $1455\left(\mathrm{CH}\right.$ of $\left.\mathrm{CH}_{2}\right) .{ }^{1} \mathrm{H}$ NMR $\left(200 \mathrm{MHz}, \mathrm{DMSO}-\mathrm{d}_{6}\right): \delta=1.60$ (br.s, $\left.6 \mathrm{H}, \mathrm{C}_{\mathrm{Ad}} \mathrm{H}_{2}\right), 1.93$ (br.s, $\left.6 \mathrm{H}, \mathrm{C}_{\mathrm{Ad}} \mathrm{H}_{2}\right), 1.98$ (br.s, $\left.3 \mathrm{H}, \mathrm{C}_{\mathrm{Ad}} \mathrm{H}\right), 2.37\left(\mathrm{~s}, 3 \mathrm{H}, \mathrm{CH}_{3}\right), 2.92\left(\mathrm{~d}, 3 \mathrm{H},{ }^{3} J_{\mathrm{HH}}=3.5 \mathrm{~Hz}, \mathrm{NCH}_{3}\right)$, 2.96-3.25 (m, 2H, CH $\mathrm{CH}_{2}, 3.26-3.78\left(\mathrm{~m}, 2 \mathrm{H}, \mathrm{CH}_{2}\right), 4.07-4.35\left(\mathrm{~m}, 1 \mathrm{H}, \mathrm{CH}_{2}\right), 4.05(\mathrm{~d}, 1 \mathrm{H}$, $\left.{ }^{2} J_{\mathrm{HH}}=12.6 \mathrm{~Hz}, \mathrm{CH}_{2}\right), 4.76\left(\mathrm{~s}, 2 \mathrm{H}, \mathrm{CH}_{2} \mathrm{C}(\mathrm{O})\right), 6.94\left(\mathrm{~d}, 1 \mathrm{H},{ }^{3} J_{\mathrm{HH}}=8.1 \mathrm{~Hz}, \mathrm{C}_{\mathrm{Ar}} \mathrm{H}\right), 7.18(\mathrm{~s}, 1 \mathrm{H}$, $\left.\mathrm{C}_{\mathrm{Ar}} \mathrm{H}\right), 7.32\left(\mathrm{~d}, 1 \mathrm{H},{ }^{3} J_{\mathrm{HH}}=8.6 \mathrm{~Hz}, \mathrm{C}_{\mathrm{Ar}} \mathrm{H}\right), 8.04$ (br. S, $\left.1 \mathrm{H}, \mathrm{NH}\right), 11.23$ (br.s, $\left.1 \mathrm{H}, \mathrm{NH}^{+} \mathrm{CH}_{3}\right)$. ${ }^{13} \mathrm{C}$ NMR (50 MHz, DMSO-d 6$): \delta=19.19\left(\mathrm{CH}_{2}\right), 21.03\left(\mathrm{CH}_{3}\right), 28.68(\mathrm{CH}), 35.88\left(\mathrm{CH}_{2}\right), 40.33$ $\left(\mathrm{CH}_{2}\right), 41.40\left(\mathrm{CH}_{3}\right), 46.03\left(\mathrm{CH}_{2}\right), 49.47\left(\mathrm{CH}_{2}\right), 49.97\left(\mathrm{CH}_{2}\right), 51.06(\mathrm{C}), 100.77(\mathrm{C}), 109.33(\mathrm{CH})$, 117.06 (CH), $122.76(\mathrm{CH}), 124.48(\mathrm{C}), 127.83(\mathrm{C}), 131.87(\mathrm{C}), 135.27(\mathrm{C}), 166.21(\mathrm{C}=\mathrm{O})$. Anal. C 70.24, H 8.21, N 9.74\%. Calcd. For $\mathrm{C}_{25} \mathrm{H}_{34} \mathrm{ClN}_{3} \mathrm{O}, \mathrm{C} 70.15, \mathrm{H} 8.01, \mathrm{~N} 9.82 \%$.

$\mathrm{N}$-(Adamantan-1-yl)-2-(8-fluoro-2-methyl-3,4-dihydro-1H-pyrido[4,3-b]indol-5(2H)yl)acetamide hydrochloride (8f). Pale brown solid. Yield $74 \%$. Mp $230-232^{\circ} \mathrm{C}$. FT IR ( $\mathrm{KBr}$ $v_{\max }$ in $\left.\mathrm{cm}^{-1}\right): 3406(\mathrm{NH}), 3263(\mathrm{CONH}), 2910\left(\mathrm{CH}_{2}\right), 2849\left(\mathrm{NCH}_{3}\right), 1679(\mathrm{C}=\mathrm{O}), 1542(\mathrm{NH}$ of amide), $1460\left(\mathrm{CH}\right.$ of $\left.\mathrm{CH}_{2}\right) .{ }^{1} \mathrm{H}$ NMR $\left(200 \mathrm{MHz}, \mathrm{DMSO}-\mathrm{d}_{6}\right): \delta=1.68\left(\mathrm{br} . \mathrm{s}, 6 \mathrm{H}, \mathrm{C}_{\mathrm{Ad}} \mathrm{H}_{2}\right)$, 1.91 (br.s, $\left.9 \mathrm{H}, \mathrm{C}_{\mathrm{Ad}} \mathrm{H}+\mathrm{C}_{\mathrm{Ad}} \mathrm{H}_{2}\right), 2.88\left(\mathrm{~s}, 3 \mathrm{H}, \mathrm{NCH}_{3}\right), 2.91-3.30\left(\mathrm{~m}, 2 \mathrm{H}, \mathrm{CH}_{2}\right), 3.36-3.82(\mathrm{~m}$, $\left.2 \mathrm{H}, \mathrm{CH}_{2}\right), 4.35\left(\mathrm{~s}, 2 \mathrm{H}, \mathrm{CH}_{2}\right), 4.76\left(\mathrm{~s}, 2 \mathrm{H}, \mathrm{CH}_{2} \mathrm{C}(\mathrm{O})\right), 6.96\left(\mathrm{t}, 1 \mathrm{H},{ }^{3} J_{\mathrm{HF}}={ }^{3} J_{\mathrm{HH}}=9.0 \mathrm{~Hz}, \mathrm{C}_{\mathrm{Ar}} \mathrm{H},\right)$, $7.22\left(\mathrm{~d}, 1 \mathrm{H},{ }^{3} J_{\mathrm{HH}}=8.5 \mathrm{~Hz}, \mathrm{C}_{\mathrm{Ar}} \mathrm{H},\right), 7.47\left(\mathrm{dd}, 1 \mathrm{H},{ }^{3} J_{\mathrm{HH}}=9.0 \mathrm{~Hz},{ }^{4} J_{\mathrm{HF}}=4.5 \mathrm{~Hz}, \mathrm{C}_{\mathrm{Ar}} \mathrm{H},\right)$, 8.15 (s, $1 \mathrm{H}, \mathrm{NH}), 11.32$ (br.s, $\left.1 \mathrm{H}, \mathrm{NH}^{+} \mathrm{CH}_{3}\right) .{ }^{13} \mathrm{C}$ NMR (50 MHz, DMSO-d 6 ): $\delta=19.33$ $\left(\mathrm{CH}_{2}\right), 28.69(\mathrm{CH}), 35.87\left(\mathrm{CH}_{2}\right), 40.82\left(\mathrm{CH}_{2}\right), 41.41\left(\mathrm{CH}_{3}\right), 46.16\left(\mathrm{CH}_{2}\right), 49.29\left(\mathrm{CH}_{2}\right), 49.87$ $\left(\mathrm{CH}_{2}\right), 51.12(\mathrm{C}), 101.60\left(\mathrm{~d},{ }^{4} J_{\mathrm{CF}}=4.4 \mathrm{~Hz}, \mathrm{C}\right), 102.67\left(\mathrm{~d},{ }^{2} J_{\mathrm{CF}}=24.5 \mathrm{~Hz}, \mathrm{CH}\right), 109.12(\mathrm{~d}$, $\left.{ }^{2} J_{\mathrm{CF}}=26.0 \mathrm{~Hz}, \mathrm{CH}\right), 110.71\left(\mathrm{~d},{ }^{3} J_{\mathrm{CF}}=9.5 \mathrm{~Hz}, \mathrm{CH}\right), 124.48\left(\mathrm{~d},{ }^{3} J_{\mathrm{CF}}=10.2 \mathrm{~Hz}, \mathrm{C}\right), 133.56(\mathrm{C})$, 
$133.93(\mathrm{C}), 157.03\left(\mathrm{~d},{ }^{1} J_{\mathrm{CF}}=232.0 \mathrm{~Hz}, \mathrm{CF}\right), 166.01(\mathrm{C}=\mathrm{O}) .{ }^{19} \mathrm{~F}$ NMR $\left(188 \mathrm{MHz}, \mathrm{DMSO}-\mathrm{d}_{6}\right)$ : $\delta=-116.9\left(\mathrm{td}, 1 \mathrm{~F},{ }^{3} J_{\mathrm{FH}}=8.5 \mathrm{~Hz},{ }^{4} J_{\mathrm{FH}}=4.5 \mathrm{~Hz}, \mathrm{CF}\right)$. Anal. C 66.70, H 7.41, N 9.92\%. Calcd. For $\mathrm{C}_{24} \mathrm{H}_{31} \mathrm{ClFN}_{3} \mathrm{O}, \mathrm{C} 66.73, \mathrm{H} 7.23, \mathrm{~N} 9.73 \%$.

\subsection{Evaluation of the Effect of New Compounds on NMDA-Receptors by a Radioligand Binding Assay}

The effect of the test compounds on radioligand binding to NMDA receptors was evaluated by a modified method, as previously reported [83]. The following two radioligands were used: $\left[{ }^{3} \mathrm{H}\right] \mathrm{MK}-801$ (dizocilpine) with a specific activity of $210 \mathrm{Ci} / \mathrm{mmol}$, binding to all isolated NMDA receptors; and $\left[{ }^{3} \mathrm{H}\right]$ ifenprodil with a specific activity of $79 \mathrm{Ci} / \mathrm{mmol}$, binding only to NMDA receptors containing the NR2B subunit [84,85]. A hippocampal membrane preparation for the radioligand binding assay was made as described previously $[86,87]$. The obtained membrane pellet was resuspended in a working buffer ( $5 \mathrm{mM}$ HEPES/4.5 mM Tris, $\mathrm{pH} 7.6$ at $4{ }^{\circ} \mathrm{C}$ ) in a ratio of $1: 5$ and stored in liquid nitrogen. The reaction mixture (the final volume was $0.5 \mathrm{~mL}$ ) contained the working buffer $(200 \mu \mathrm{L})$, a $50 \mathrm{nM}$ radioligand solution $(50 \mu \mathrm{L})$ and the membrane suspension $(250 \mu \mathrm{L})$. The nonspecific binding was evaluated in the presence of $1 \mathrm{mM}$ of the unlabeled ligand $(50 \mu \mathrm{L})$.

For the binding assay, the reaction mixture was incubated at room temperature for $2 \mathrm{~h}$. After the incubation, the samples were filtered through GF/B glass fiber filters (Whatman), washed with the working buffer, dried and transferred to scintillation vials. Then the scintillation fluid (5 mL), which is composed of diphenyloxazole (PPO) (4 g) and bis(5phenyl-2-oxazolyl)benzene (POPOP) $(0.2 \mathrm{~g})$ in toluene $(1 \mathrm{~L})$ were added to the vials. The radioactivity was measured with a TriCarb2800 TR scintillation counter (Perkin Elmer, Waltham, MA, USA) with a counting efficiency of about $65 \%$.

The effect of the test compounds on the binding of $\left[{ }^{3} \mathrm{H}\right] \mathrm{MK}-801$ and $\left[{ }^{3} \mathrm{H}\right]$ ifenprodil to rat hippocampal membranes was evaluated by the addition of the test compounds $(50 \mu \mathrm{L})$ to the incubation medium in the concentration range of $10^{-8}-10^{-3} \mathrm{M}$. The $\mathrm{IC}_{50}$ values for the test compounds were calculated from the inhibition data with GraphPad Prism 4 (Supplement Figure S5). The values of $K_{\mathrm{i}}$ were calculated according to a previously described method [88].

\subsection{Analysis of the Esterase Profile of Compounds and Inhibition Kinetics of AChE and BChE}

Kinetic studies were performed using commercial human erythrocyte AChE, equine serum BChE and porcine liver CES (Sigma, USA). The AChE and BChE activity was evaluated by Ellman's method $(\lambda=412 \mathrm{~nm})$ [89] using $1 \mathrm{mM}$ acetylthiocholine and $1 \mathrm{mM}$ butyrylthiocholine (Sigma, St. Louis, MO, USA), respectively, as the substrate in $100 \mathrm{mM}$ phosphate buffer, $\mathrm{pH} 7.5,0.33 \mathrm{mM}$ DTNB, 0.02 unit/mL of $\mathrm{AChE}$ or $\mathrm{BChE}$ at $25{ }^{\circ} \mathrm{C}$ as described in detail in [71]. Reagents blanks consisted of reaction mixtures without substrates. The CES activity was measured spectrophotometrically based on the release of 4nitrophenol $(\lambda=405 \mathrm{~nm})$ in the presence of $1 \mathrm{mM}$ 4-nitrophenyl acetate as the substrate [90] in $100 \mathrm{mM}$ phosphate buffer, $\mathrm{pH} \mathrm{8.0,} \mathrm{at} 25^{\circ} \mathrm{C}$ as described in [71]. Final enzyme and substrate concentrations were $0.02 \mathrm{unit} / \mathrm{mL}$ and $1 \mathrm{mM}$, respectively. Assays were carried out with a blank containing all constituents except porcine CES to assess non-enzymatic hydrolysis. The measurements were performed on a FLUOstar OPTIMA multifunctional microplate reader (BMG LABTECH, Ortenberg, Germany). The compounds were dissolved in DMSO. The incubation mixture contained $2 \%(v / v)$ of the solvent. The primary inhibitory activity of the test compounds was determined by the measurement of the degree of inhibition of the enzymes with a $20 \mu \mathrm{M}$ concentration of the compound. The sample of the appropriate enzyme was incubated with the test compound for $5 \mathrm{~min}$, and then the residual enzymatic activity was determined. Each experiment was performed in triplicate. The $\mathrm{IC}_{50}$ values, i.e., the concentration of the compounds required for $50 \%$ inhibition of the enzyme, were determined for the most active compounds. To measure the $\mathrm{IC}_{50}$ values of AChE, BChE and CES inhibition, the samples of the enzymes were incubated with the test compound in the concentration range of $1 \times 10^{-12}-1 \times 10^{-4} \mathrm{M}$ for $5 \mathrm{~min}$, and then the residual enzymatic activity was evaluated. Each experiment was performed in triplicate. 
The $\mathrm{IC}_{50}$ values were calculated with Origin 6.1 software. Tacrine, an effective $\mathrm{AChE}$ and $\mathrm{BChE}$ inhibitor, and bis-4-nitrophenyl phosphate (BNPP), a selective CES inhibitor, were employed as the positive controls.

The mechanisms of AChE and BChE inhibition were assessed by a thorough analysis of enzyme kinetics. The residual activity was determined after a 5-min incubation at $25{ }^{\circ} \mathrm{C}$ (for temperature equilibration) with three increasing concentrations of the inhibitor and six decreasing substrate concentrations. The inhibition constants $K_{\mathrm{i}}$ (a competitive component) and $\alpha K_{\mathrm{i}}$ (a noncompetitive component) were determined by the linear regression of $1 / \mathrm{V}$ versus $1 /[\mathrm{S}]$ double-reciprocal (Lineweaver-Burk) plots.

\subsection{Displacement of Propidium Iodide from AChE PAS}

The compounds were evaluated as potential inhibitors of proaggregation activity of AChE by measuring the displacement of propidium iodide from the PAS of the enzyme [53] using a fluorescence method [28]. AChE from Electrophorus electricus (EeAChE, type VI-S, lyophilized powder, Sigma-Aldrich, St. Louis, MO, USA) was used for consistency with our previous studies $[8,13,63,74]$. The fluorescence intensity of propidium iodide bound to $\mathrm{AChE}$ increases several-fold. A decrease in the fluorescence intensity in the presence of the test compounds is indicative of their ability to bind to the AChE PAS and, correspondingly, to inhibit $\beta$-amyloid aggregation.

EeAChE $(7 \mu \mathrm{M})$ was incubated with $20 \mu \mathrm{M}$ of the test compound in $1 \mathrm{mM}$ Tris- $\mathrm{HCl}$ buffer, $\mathrm{pH} 8.0$, at $25^{\circ} \mathrm{C}$ for $15 \mathrm{~min}$. Then a solution of propidium iodide was added (final concentration $8 \mu \mathrm{M}$ ), the mixture was incubated for $15 \mathrm{~min}$, and the fluorescence spectrum was recorded (excitation at $530 \mathrm{~nm}$ and emission at $600 \mathrm{~nm}$ ). Donepezil and tacrine were used as the reference compounds. The blank contained propidium iodide at the same concentration in $1 \mathrm{mM}$ Tris- $\mathrm{HCl}$ buffer, $\mathrm{pH} 8.0$ at $25^{\circ} \mathrm{C}$. The measurements were performed in triplicate on a FLUOstar OPTIMA multifunctional microplate reader.

The degree of displacement of propidium iodide from the PAS of AChE (\% displacement) was calculated by the equation:

$$
\% \text { displacement }=100-\left(\mathrm{IF}_{\mathrm{AChE}}+\text { Propidium }+ \text { inhibitor } / \mathrm{IF}_{\mathrm{AChE}}+\text { Propidium }\right) \times 100,
$$

where $\mathrm{IF}_{\mathrm{AChE}}+$ Propidium is the fluorescence intensity of propidium iodide bound to $E e \mathrm{AChE}$ in the absence of the test compound (taken as $100 \%$ ), and $\mathrm{IF}_{\mathrm{AChE}}+$ Propidium + inhibitor is the fluorescence intensity of propidium iodide bound to $E e \mathrm{AChE}$ in the presence of the test compound.

\subsection{Investigation of the Effect of the Compounds on Mitochondrial Characteristics}

Experiments were performed using outbred male rats weighing 200-220 g. The animals were housed under standard vivarium conditions in a normal day/night cycle and had ad libitum access to water and food. The procedure of rat euthanasia using carbon dioxide $\left(\mathrm{CO}_{2}\right)$ inhalation for mitochondria preparation is in compliance with the Guidelines for Animal Experiments, which were approved by the local bioethics committee of the IPAC RAS.

Rat liver mitochondria were isolated by conventional differential centrifugation [91]. Membrane potential of rat liver mitochondria was measured using the potential-sensitive fluorescent probe Safranine A on a Victor 3 multilabel plate reader (Perkin Elmer, Waltham, MA, USA). The fluorescence was recorded at $\lambda_{\mathrm{ex}}=485 \mathrm{~nm}$ and $\lambda_{\mathrm{em}}=590 \mathrm{~nm}$ [92]. Mitochondrial swelling was measured by spectrophotometry in 96-well clear bottom plates on a Victor 3 microplate reader (Perkin Elmer, Waltham, MA, USA) at $620 \mathrm{~nm} ; \mathrm{CaCl}_{2}$ was added to induce mitochondrial swelling (MPT opening) [20].

\subsection{MTT Assay}

The MTT assay is commonly used to evaluate cell viability after exposure to toxic substances and is based on the ability of dehydrogenases of living cells, in particular, succinate dehydrogenase, to reduce colorless 3-(4,5-dimethylthiazol-2-yl)-2-5-diphenyltetrazolium 
salts (MTT reagent) to blue crystalline formazan, which is soluble in dimethyl sulfoxide. The MTT assay was performed by a slightly modified procedure [93] after a 24-h incubation of SH-SY5Y cells with the test compound at a concentration of $30 \mu \mathrm{M}$. The concentration of reduced product was measured colorimetrically on a Victor 3 microplate reader (Perkin Elmer, USA) based on the difference in absorbance of the sample at wavelengths of 540-620 nm.

\subsection{Evaluation of the Effect of Compounds on Tubulin Polymerization}

A crude fraction of tubulin and microtubule-associated proteins (Tb+MAP) was isolated from mouse brain tissue by a polymerization-depolymerization method [94]. The procedure of mouse euthanasia using cervical dislocation for $\mathrm{Tb}+\mathrm{MAP}$ preparation is in compliance with the Guidelines for Animal Experiments, which were approved by the local bioethics committee of the IPAC RAS. The freshly dissected brain was immediately placed on ice, cleared of meninges and surface blood vessels, and washed with cold buffer A (50 mM Tris-HCl, pH 6.9 at $4{ }^{\circ} \mathrm{C}, 2 \mathrm{mM}$ EGTA). The extracted brain tissue was homogenized under ice cooling in the same buffer using a Potter $\mathrm{S}$ homogenizer (Sartorius). The resulting homogenate was centrifuged at 10,000 $\times \mathrm{g}$ for $30 \mathrm{~min}$ on an Avanti 25 centrifuge (Beckman) using a JA-14 rotor for the precipitation of non-ruptured cells. The precipitate was discarded, and the supernatant was again centrifuged at 100,000 $\times g$ for $60 \mathrm{~min}$ at $4{ }^{\circ} \mathrm{C}$ on an Optima MAX XP centrifuge (Beckman) using a MLA-50 rotor. The precipitate was again discarded. The protein concentration in the supernatant was determined by the Bradford assay using the Bio-Rad Protein Assay kit (Bio-Rad, Hercules, CA, USA) according to manufacturer's instructions. The resulting supernatant was a cytosolic fraction enriched in microtubular proteins ( $\mathrm{Tb}$ and MAP).

The $\mathrm{Tb}+\mathrm{MAP}$ preparation was centrifuged at $5000 \times \mathrm{g}$ for $10 \mathrm{~min}$ at $4{ }^{\circ} \mathrm{C}$ immediately before polymerization in order to remove denatured and aggregated protein molecules by precipitation. The $\mathrm{Tb}+\mathrm{MAP}$ polymerization was performed at $37^{\circ} \mathrm{C}$ in buffer $\mathrm{A}$ in the presence of $0.1 \mathrm{mM}$ GTP after addition of $100 \mu \mathrm{M}$ of test compound or the same volume of vehicle (DMSO). The protein concentration in the sample was $0.2 \mathrm{mg} / \mathrm{mL}$. The polymerization kinetics was monitored on a Victor 3 or EnVision microplate reader (Perkin Elmer, USA) at $355 \mathrm{~nm}$ and the stabilized rate of polymerization after the first wave was measured $\left(\mathrm{dA}_{355} / \mathrm{dt}\right)$.

\subsection{Molecular Modeling}

To prepare the structures for molecular modeling, the protonation state of compounds was selected based on the estimated $\mathrm{p} K_{\mathrm{a}}$ of ionogenic groups with Marvin 16.6.13.0 software (ChemAxon, http: / / www.chemaxon.com (accessed on 23 August 2021)). Geometry optimization of the ligands was carried out using GAMESS-US software [95] using DFT functional B3LYP with the 6-31G* basis set. Molecular docking of ligands into the active sites of AChE and BChE was performed using crystal structures PDB ID 4EY4 [66] and PDB ID 1P0I [96], respectively. The protein structure was prepared, saturated with water molecules, and optimized by the QM/MM method as reported previously [97]. Molecular docking was carried out with the Lamarckian genetic algorithm (LGA) [98] implemented in Autodock software 4.2.6 [99]. The grid box for docking included the entire active site gorge of $\mathrm{AChE}(22.5 \AA \times 22.5 \AA \times 22.5 \AA$ grid box dimensions $)$ and $\mathrm{BChE}(15 \AA \times 20.25 \AA \times 18 \AA$ grid box dimensions) with a grid spacing of $0.375 \AA$. The following LGA parameters were used: 256 runs, $27 \times 10^{4}$ generations, population size 3000 and $25 \times 10^{6}$ evaluations.

\section{Conclusions}

All of the new compounds exhibited activity in the primary screening assays used in this study and possessed a multifunctional type of action. Thus, the compounds inhibited $\mathrm{AChE}$ and $\mathrm{BChE}$, demonstrating stronger inhibitory activity against $\mathrm{BChE}$, but had almost no effect on the activity of CES, which is an anti-target for anticholinesterase agents. The compounds were NMDA-subtype glutamate receptor ligands, exhibited mitoprotective 
properties, increased the resistance of mitochondria to the MPT pore opening and acted as microtubule stabilizers stimulating the polymerization of tubulin and microtubuleassociated proteins. A new property of the conjugates, which is absent in the agents containing only one pharmacologically active scaffold (memantine and dimebon), was revealed: the ability to occupy the PAS of $\mathrm{AChE}$, which could confer a disease-modifying effect of blocking AChE-induced $\beta$-amyloid aggregation.

Unexpected results were obtained in the study of the effect of the compounds on NMDA receptors. In particular, the conjugates containing memantine, the specific ligand of the intra-channel site of the NMDA receptor, exhibited activity against this site comparable with that of the conjugates with amantadine, which itself does not show any notable activity toward this target. In general, the modification of the polycyclic scaffolds in the tested conjugates did not have a significant effect on the activity of the compounds. It should be emphasized that the synthesized conjugates exhibited a new type of activity compared to the prototypes (dimebon and memantine) — the ability to block the ifenprodil-binding site of the NMDA receptor.

The spacer structure had a substantial effect on the activity of the compounds. In all cases, except for the stimulation of tubulin polymerization, the use of the ethylene spacer instead of the 1-oxoethylene one significantly enhanced interactions with the studied targets. Namely, this spacer configuration improved the binding of the conjugates to both sites of the NMDA receptor, increased the anti-BChE activity and enhanced the ability to inhibit MPT pore opening. In addition, the conjugates linked via the ethylene spacer could moderately inhibit AChE and block AChE-induced $\beta$-amyloid aggregation. In the series of new compounds, there were several hits, where conjugates linked via the ethylene spacer were revealed, and in this series, several potential lead compounds (4a, $\mathbf{4 c}, \mathbf{4 d}, \mathbf{4 f})$ were selected. Taking into account the efficacy of these compounds toward the selected targets, they would be expected to have cognitive-enhancing, neuroprotective, anti-amyloid and microtubulestabilizing activity. Therefore, the investigation of the newly synthesized conjugated structures bearing scaffolds of the known neuroactive agents (memantine and dimebon) resulted in the synthesis of a novel group of multipharmacophore compounds and revealed unexpected properties that were not inherent to the background "monopharmacophore" agents. As well as previously described aminoadamantane-carbazole derivatives [9], the newly synthesized conjugates look highly promising as potential multifunctional agents that act simultaneously on a number of key biological targets involved in the pathogenesis of neurodegenerative processes. Preclinical trials of safety and tolerance of lead compounds could permit the selection of the most promising drug candidates for further development.

Supplementary Materials: The following are available online: Table S1, Docking scores of aminoadamantane- $\gamma$-carboline conjugates; Figure $\mathrm{S1}, \mathrm{IC}_{50}$ values for $\mathrm{hAChE}$ inhibition by compounds 4 (MEAN $\pm \mathrm{SEM}, n=3$ ); Figure S2, $\mathrm{IC}_{50}$ values for eqBChE inhibition by compounds 4, 8 (MEAN \pm SEM, $n=3$ ); Figure S3, Docking of conjugates linked via ethylene and 1-oxoethylene spacers to BChE (a) Figure 4 overlapped with binding pose of dimebon (carbon atoms are shown in orange) (b) Figure 3a overlapped with binding pose of donepezil (carbon atoms are shown in bright green), viewpoint differs from the original figures in the text; Figure S4, Docking of conjugates 4 linked via ethylene spacer to AChE (a) Figure 5a overlapped with binding pose of donepezil (carbon atoms are shown in bright green) (b) Figure $5 \mathrm{~b}$ overlapped with binding pose of donepezil (carbon atoms are shown in bright green) (c) Figure 5 b overlapped with binding pose of dimebon (carbon atoms are shown in orange), viewpoint differs from the original figures in the text; Figure S5, Calculation of $\mathrm{IC}_{50}$ values for compounds binding with MK-801 specific site of NMDA receptor (MEAN $\pm \mathrm{SEM}, n=3$ ); Figure S6, Calculation of $\mathrm{IC}_{50}$ values for compounds binding with ifenprodil specific site of NMDA receptor $(\mathrm{MEAN} \pm \mathrm{SEM}, n=3)$.

Author Contributions: Conceptualization, methodology, S.O.B., G.F.M., E.F.S. and S.V.L.; synthesis, A.Y.A., T.V.G. and T.A.E.; experimental investigation, V.V.G., P.N.S., N.V.K., E.V.R., N.P.B., V.L.Z., A.V.G., E.A.P. and L.G.D.; computer modeling, S.V.L. and R.J.R.; writing-original draft preparation, S.O.B., E.F.S., E.V.R., A.Y.A., N.V.K., N.P.B., S.V.L., G.F.M., V.V.G. and V.P.F.; writing-review and editing, S.O.B., G.F.M., E.F.S., N.V.K., S.V.L., N.P.B., E.V.R., R.J.R. and A.Y.A.; writing-graphics 
preparation, text formatting, manuscript preparing E.V.B.; supervision, S.O.B. All authors have read and agreed to the published version of the manuscript.

Funding: This work was financially supported within the framework of the grant agreement as government subsidies from the Federal budget in accordance with paragraph 4 of article 78.1 of the Budget Code of the Russian Federation (Moscow, 1 October 2020, No. 075-15-2020-777).

Institutional Review Board Statement: The use of rodents for study was conducted according to the guidelines of the Declaration of Helsinki, and the used in this study procedures of rodent euthanasia for mitochondria or Tb+MAP preparation are in compliance with the Guidelines for Animals Experiments, which were approved by the local bioethics committee of the Institute of Physiologically Active Compounds of the Russian Academy of Sciences.

Acknowledgments: We thank the shared research facilities of the HPC computing resources at Lomonosov Moscow State University [100] for supercomputer time and the "Centre for Collective Use of IPAC RAS" for use of equipment cited in the Methods.

Conflicts of Interest: The authors declare no conflict of interest.

Sample Availability: Not available.

$\begin{array}{ll}\text { Abbreviations } \\ \text { AChE } & \text { acetylcholinesterase; } \\ \text { BChE } & \text { butyrylcholinesterase; } \\ \text { BNPP } & \text { bis-4-nitrophenyl phosphate; } \\ \text { CAS } & \text { catalytic active site; } \\ \text { CES } & \text { carboxylesterase; } \\ \text { DMSO } & \text { dimethyl sulfoxide; } \\ \text { EeAChE } & \text { AChE from Electrophorus electricus; } \\ \text { MPT } & \text { mitochondrial permeability transition; } \\ \text { PAS } & \text { peripheral anionic site; } \\ \text { QM/MM } & \text { quantum mechanics/molecular mechanics; } \\ \text { Tb+MAP } & \text { tubulin and microtubule-associated proteins. }\end{array}$

\section{References}

1. World Alzheimer Report 2018 The State of the Art of Dementia Research: New Frontiers; Alzheimer's Disease International (ADI): London, UK, 2018.

2. Bachurin, S.O.; Gavrilova, S.I.; Samsonova, A.; Barreto, G.E.; Aliev, G. Mild cognitive impairment due to Alzheimer disease: Contemporary approaches to diagnostics and pharmacological intervention. Pharmacol. Res. 2018, 129, 216-226. [CrossRef] [PubMed]

3. Liu, P.P.; Xie, Y.; Meng, X.Y.; Kang, J.S. History and progress of hypotheses and clinical trials for Alzheimer's disease. Signal Transduct.Target Ther. 2019, 4, 29. [CrossRef] [PubMed]

4. Long, J.M.; Holtzman, D.M. Alzheimer Disease: An Update on Pathobiology and Treatment Strategies. Cell 2019, 179, 312-339. [CrossRef]

5. Calabro, M.; Rinaldi, C.; Santoro, G.; Crisafulli, C. The biological pathways of Alzheimer disease: A review. AIMS Neurosci. 2021, 8, 86-132. [CrossRef] [PubMed]

6. Albertini, C.; Salerno, A.; de Sena Murteira Pinheiro, P.; Bolognesi, M.L. From combinations to multitarget-directed ligands: A continuum in Alzheimer's disease polypharmacology. Med. Res. Rev. 2021, 41, 2606-2633. [CrossRef]

7. Bachurin, S.O.; Bovina, E.V.; Ustyugov, A.A. Drugs in Clinical Trials for Alzheimer's Disease: The Major Trends. Med. Res. Rev. 2017, 37, 1186-1225. [CrossRef]

8. $\quad$ Bachurin, S.O.; Makhaeva, G.F.; Shevtsova, E.F.; Boltneva, N.P.; Kovaleva, N.V.; Lushchekina, S.V.; Rudakova, E.V.; Dubova, L.G.; Vinogradova, D.V.; Sokolov, V.B.; et al. Conjugates of methylene blue with gamma-carboline derivatives as new multifunctional agents for the treatment of neurodegenerative diseases. Sci. Rep. 2019, 9, 4873. [CrossRef] [PubMed]

9. Bachurin, S.O.; Shevtsova, E.F.; Makhaeva, G.F.; Grigoriev, V.V.; Boltneva, N.P.; Kovaleva, N.V.; Lushchekina, S.V.; Shevtsov, P.N.; Neganova, M.E.; Redkozubova, O.M.; et al. Novel conjugates of aminoadamantanes with carbazole derivatives as potential multitarget agents for AD treatment. Sci. Rep. 2017, 7, 45627. [CrossRef] [PubMed]

10. Makhaeva, G.F.; Lushchekina, S.V.; Boltneva, N.P.; Sokolov, V.B.; Grigoriev, V.V.; Serebryakova, O.G.; Vikhareva, E.A.; Aksinenko, A.Y.; Barreto, G.E.; Aliev, G.; et al. Conjugates of $\gamma$-carbolines and phenothiazine as new selective inhibitors of butyrylcholinesterase and blockers of NMDA receptors for Alzheimer disease. Sci. Rep. 2015, 5, 13164. [CrossRef] 
11. Makhaeva, G.F.; Sokolov, V.B.; Shevtsova, E.F.; Kovaleva, N.V.; Lushchekina, S.V.; Boltneva, N.P.; Rudakova, E.V.; Aksinenko, A.Y.; Shevtsov, P.N.; Neganova, M.E.; et al. Focused design of polypharmacophoric neuroprotective compounds: Conjugates of $\gamma$-carbolines with carbazole derivatives and tetrahydrocarbazole. Pure Appl. Chem. 2017, 89, 1167-1184. [CrossRef]

12. Makhaeva, G.F.; Shevtsova, E.F.; Boltneva, N.P.; Lushchekina, S.V.; Kovaleva, N.V.; Rudakova, E.V.; Bachurin, S.O.; Richardson, R.J. Overview of novel multifunctional agents based on conjugates of $\gamma$-carbolines, carbazoles, tetrahydrocarbazoles, phenothiazines, and aminoadamantanes for treatment of Alzheimer's disease. Chem. Biol. Interact. 2019, 308, 224-234. [CrossRef]

13. Makhaeva, G.F.; Shevtsova, E.F.; Aksinenko, A.Y.; Kovaleva, N.V.; Boltneva, N.P.; Lushchekina, S.V.; Rudakova, E.V.; Pushkareva, E.A.; Serkova, T.P.; Dubova, L.G.; et al. Bis- $\gamma$-carbolines as new potential multitarget agents for Alzheimer's disease. Pure Appl. Chem. 2020, 92, 1057-1080. [CrossRef]

14. Lipton, S. The Molecular Basis of Memantine Action in Alzheimers Disease and Other Neurologic Disorders: Low-affinity, Uncompetitive Antagonism. Curr. Alzheimer Res. 2005, 2, 155-165. [CrossRef] [PubMed]

15. Kabir, M.T.; Sufian, M.A.; Uddin, M.S.; Begum, M.M.; Akhter, S.; Islam, A.; Mathew, B.; Islam, M.S.; Amran, M.S.; Md Ashraf, G. NMDA Receptor Antagonists: Repositioning of Memantine as a Multitargeting Agent for Alzheimer's Therapy. Curr. Pharm. Des. 2019, 25, 3506-3518. [CrossRef]

16. Doody, R.S.; Gavrilova, S.I.; Sano, M.; Thomas, R.G.; Aisen, P.S.; Bachurin, S.O.; Seely, L.; Hung, D. Effect of dimebon on cognition, activities of daily living, behaviour, and global function in patients with mild-to-moderate Alzheimer's disease: A randomised, double-blind, placebo-controlled study. Lancet 2008, 372, 207-215. [CrossRef]

17. Bharadwaj, P.R.; Bates, K.A.; Porter, T.; Teimouri, E.; Perry, G.; Steele, J.W.; Gandy, S.; Groth, D.; Martins, R.N.; Verdile, G. Latrepirdine: Molecular mechanisms underlying potential therapeutic roles in Alzheimer's and other neurodegenerative diseases. Transl. Psychiatry 2013, 3, e332. [CrossRef]

18. Eckert, S.H.; Gaca, J.; Kolesova, N.; Friedland, K.; Eckert, G.P.; Muller, W.E. Mitochondrial Pharmacology of Dimebon (Latrepirdine) Calls for a New Look at its Possible Therapeutic Potential in Alzheimer's Disease. Aging Dis. 2018, 9, 729-744. [CrossRef]

19. Ustyugov, A.; Shevtsova, E.; Ashraf, G.M.; Tarasov, V.V.; Bachurin, S.O.; Aliev, G. New Therapeutic Property of Dimebon as a Neuroprotective Agent. Curr. Med. Chem. 2018, 25, 5315-5326. [CrossRef]

20. Shevtsova, E.F.; Vinogradova, D.V.; Kireeva, E.G.; Reddy, V.P.; Aliev, G.; Bachurin, S.O. Dimebon attenuates the Abeta-induced mitochondrial permeabilization. Curr. Alzheimer Res. 2014, 11, 422-429. [CrossRef]

21. Ustyugov, A.; Shevtsova, E.; Bachurin, S. Novel Sites of Neuroprotective Action of Dimebon (Latrepirdine). Mol. Neurobiol. 2015, 52, 970-978. [CrossRef] [PubMed]

22. Wu, J.; Li, Q.; Bezprozvanny, I. Evaluation of Dimebon in cellular model of Huntington's disease. Mol. Neurodegener. 2008, 3, 15. [CrossRef]

23. Sokolov, V.B.; Aksinenko, A.Y.; Epishina, T.A.; Goreva, T.V. Vinylation of Tetrahydro- $\gamma$-carbolines. Russ. J. Gen. Chem. 2018, 88, 1931-1933. [CrossRef]

24. Bukke, V.N.; Archana, M.; Villani, R.; Romano, A.D.; Wawrzyniak, A.; Balawender, K.; Orkisz, S.; Beggiato, S.; Serviddio, G.; Cassano, T. The Dual Role of Glutamatergic Neurotransmission in Alzheimer's Disease: From Pathophysiology to Pharmacotherapy. Int. J. Mol. Sci. 2020, 21, 7452. [CrossRef]

25. Volianskis, A.; France, G.; Jensen, M.S.; Bortolotto, Z.A.; Jane, D.E.; Collingridge, G.L. Long-term potentiation and the role of N-methyl-D-aspartate receptors. Brain. Res. 2015, 1621, 5-16. [CrossRef]

26. Pagano, J.; Giona, F.; Beretta, S.; Verpelli, C.; Sala, C. N-methyl-d-aspartate receptor function in neuronal and synaptic development and signaling. Curr. Opin. Pharmacol. 2021, 56, 93-101. [CrossRef]

27. Tikhonova, I.G.; Baskin, I.I.; Palyulin, V.A.; Zefirov, N.S.; Bachurin, S.O. Structural basis for understanding structure-activity relationships for the glutamate binding site of the NMDA receptor. J. Med. Chem. 2002, 45, 3836-3843. [CrossRef] [PubMed]

28. Taylor, P.; Lappi, S. Interaction of fluorescence probes with acetylcholinesterase. Site and specificity of propidium binding. Biochemistry 1975, 14, 1989-1997. [CrossRef]

29. Ahmed, H.; Haider, A.; Ametamey, S.M. N-Methyl-D-Aspartate (NMDA) receptor modulators: A patent review (2015-present). Expert Opin. Ther. Pat. 2020, 30, 743-767. [CrossRef]

30. Companys-Alemany, J.; Turcu, A.L.; Bellver-Sanchis, A.; Loza, M.I.; Brea, J.M.; Canudas, A.M.; Leiva, R.; Vazquez, S.; Pallas, M.; Grinan-Ferre, C. A Novel NMDA Receptor Antagonist Protects against Cognitive Decline Presented by Senescent Mice. Pharmaceutics 2020, 12, 284. [CrossRef]

31. Alam, S.; Lingenfelter, K.S.; Bender, A.M.; Lindsley, C.W. Classics in Chemical Neuroscience: Memantine. ACS Chem. Neurosci. 2017, 8, 1823-1829. [CrossRef] [PubMed]

32. Limapichat, W.; Yu, W.Y.; Branigan, E.; Lester, H.A.; Dougherty, D.A. Key binding interactions for memantine in the NMDA receptor. ACS Chem. Neurosci. 2013, 4, 255-260. [CrossRef]

33. Parsons, M.P.; Raymond, L.A. Extrasynaptic NMDA receptor involvement in central nervous system disorders. Neuron 2014, 82, 279-293. [CrossRef] [PubMed]

34. Vieira, M.; Yong, X.L.H.; Roche, K.W.; Anggono, V. Regulation of NMDA glutamate receptor functions by the GluN2 subunits. J. Neurochem. 2020, 154, 121-143. [CrossRef]

35. Liu, W.; Jiang, X.; Zu, Y.; Yang, Y.; Liu, Y.; Sun, X.; Xu, Z.; Ding, H.; Zhao, Q. A comprehensive description of GluN2B-selective N-methyl-D-aspartate (NMDA) receptor antagonists. Eur. J. Med. Chem. 2020, 200, 112447. [CrossRef] 
36. Schreiber, J.A.; Schepmann, D.; Frehland, B.; Thum, S.; Datunashvili, M.; Budde, T.; Hollmann, M.; Strutz-Seebohm, N.; Wunsch, B.; Seebohm, G. A common mechanism allows selective targeting of GluN2B subunit-containing N-methyl-D-aspartate receptors. Commun. Biol. 2019, 2, 420. [CrossRef]

37. Martinez, A.; Castro, A. Novel cholinesterase inhibitors as future effective drugs for the treatment of Alzheimer's disease. Expert Opin. Investig. Drugs 2006, 15, 1-12. [CrossRef]

38. Mufson, E.J.; Counts, S.E.; Perez, S.E.; Ginsberg, S.D. Cholinergic system during the progression of Alzheimer's disease: Therapeutic implications. Expert Rev. Neurother. 2008, 8, 1703-1718. [CrossRef] [PubMed]

39. Agatonovic-Kustrin, S.; Kettle, C.; Morton, D.W. A molecular approach in drug development for Alzheimer's disease. Biomed. Pharmacother. 2018, 106, 553-565. [CrossRef] [PubMed]

40. Furukawa-Hibi, Y.; Alkam, T.; Nitta, A.; Matsuyama, A.; Mizoguchi, H.; Suzuki, K.; Moussaoui, S.; Yu, Q.S.; Greig, N.H.; Nagai, T.; et al. Butyrylcholinesterase inhibitors ameliorate cognitive dysfunction induced by amyloid-beta peptide in mice. Behav. Brain Res. 2011, 225, 222-229. [CrossRef]

41. Nordberg, A.; Ballard, C.; Bullock, R.; Darreh-Shori, T.; Somogyi, M. A review of butyrylcholinesterase as a therapeutic target in the treatment of Alzheimer's disease. Prim. Care Companion CNS Disord. 2013, 15, PCC.12r01412. [CrossRef] [PubMed]

42. Greig, N.H.; Utsuki, T.; Ingram, D.K.; Wang, Y.; Pepeu, G.; Scali, C.; Yu, Q.S.; Mamczarz, J.; Holloway, H.W.; Giordano, T.; et al. Selective butyrylcholinesterase inhibition elevates brain acetylcholine, augments learning and lowers Alzheimer beta-amyloid peptide in rodent. Proc. Natl. Acad. Sci. USA 2005, 102, 17213-17218. [CrossRef]

43. Košak, U.; Brus, B.; Knez, D.; Šink, R.; Žakelj, S.; Trontelj, J.; Pišlar, A.; Šlenc, J.; Gobec, M.; Živin, M.; et al. Development of an in-vivo active reversible butyrylcholinesterase inhibitor. Sci. Rep. 2016, 6, 39495. [CrossRef]

44. Lane, R.M.; Potkin, S.G.; Enz, A. Targeting acetylcholinesterase and butyrylcholinesterase in dementia. Int. J. Neuropsychopharmacol. 2006, 9, 101-124. [CrossRef] [PubMed]

45. Andrisano, V.; Naldi, M.; De Simone, A.; Bartolini, M. A patent review of butyrylcholinesterase inhibitors and reactivators 2010-2017. Expert Opin. Ther. Pat. 2018, 28, 455-465. [CrossRef] [PubMed]

46. Laizure, S.C.; Herring, V.; Hu, Z.; Witbrodt, K.; Parker, R.B. The role of human carboxylesterases in drug metabolism: Have we overlooked their importance? Pharmacotherapy 2013, 33, 210-222. [CrossRef] [PubMed]

47. Makhaeva, G.F.; Rudakova, E.V.; Kovaleva, N.V.; Lushchekina, S.V.; Boltneva, N.P.; Proshin, A.N.; Shchegolkov, E.V.; Burgart, Y.V.; Saloutin, V.I. Cholinesterase and carboxylesterase inhibitors as pharmacological agents. Russ. Chem. Bull. 2019, 68, 967-984. [CrossRef]

48. Hsiao, K.; Chapman, P.; Nilsen, S.; Eckman, C.; Harigaya, Y.; Younkin, S.; Yang, F.; Cole, G. Correlative memory deficits, Abeta elevation, and amyloid plaques in transgenic mice. Science 1996, 274, 99-102. [CrossRef]

49. Hardy, J.; Bogdanovic, N.; Winblad, B.; Portelius, E.; Andreasen, N.; Cedazo-Minguez, A.; Zetterberg, H. Pathways to Alzheimer's disease. J. Intern. Med. 2014, 275, 296-303. [CrossRef]

50. Moran, M.A.; Mufson, E.J.; Gomez-Ramos, P. Cholinesterases colocalize with sites of neurofibrillary degeneration in aged and Alzheimer's brains. Acta Neuropathol. 1994, 87, 284-292. [CrossRef]

51. Inestrosa, N.C.; Alvarez, A.; Pérez, C.A.; Moreno, R.D.; Vicente, M.; Linker, C.; Casanueva, O.I.; Soto, C.; Garrido, J. Acetylcholinesterase Accelerates Assembly of Amyloid- $\beta$-Peptides into Alzheimer's Fibrils: Possible Role of the Peripheral Site of the Enzyme. Neuron 1996, 16, 881-891. [CrossRef]

52. De Ferrari, G.V.; Canales, M.A.; Shin, I.; Weiner, L.M.; Silman, I.; Inestrosa, N.C. A structural motif of acetylcholinesterase that promotes amyloid beta-peptide fibril formation. Biochemistry 2001, 40, 10447-10457. [CrossRef] [PubMed]

53. Bartolini, M.; Bertucci, C.; Cavrini, V.; Andrisano, V. $\beta$-Amyloid aggregation induced by human acetylcholinesterase: Inhibition studies. Biochem. Pharmacol. 2003, 65, 407-416. [CrossRef]

54. Inestrosa, N.C.; Dinamarca, M.C.; Alvarez, A. Amyloid-cholinesterase interactions. Implications for Alzheimer's disease. FEBS J. 2008, 275, 625-632. [CrossRef]

55. Arce, M.P.; Rodriguez-Franco, M.I.; Gonzalez-Munoz, G.C.; Perez, C.; Lopez, B.; Villarroya, M.; Lopez, M.G.; Garcia, A.G.; Conde, S. Neuroprotective and cholinergic properties of multifunctional glutamic acid derivatives for the treatment of Alzheimer's disease. J. Med. Chem. 2009, 52, 7249-7257. [CrossRef] [PubMed]

56. Camps, P.; Formosa, X.; Galdeano, C.; Gomez, T.; Munoz-Torrero, D.; Ramirez, L.; Viayna, E.; Gomez, E.; Isambert, N.; Lavilla, R.; et al. Tacrine-based dual binding site acetylcholinesterase inhibitors as potential disease-modifying anti-Alzheimer drug candidates. Chem. Biol. Interact. 2010, 187, 411-415. [CrossRef] [PubMed]

57. Zueva, I.; Dias, J.; Lushchekina, S.; Semenov, V.; Mukhamedyarov, M.; Pashirova, T.; Babaev, V.; Nachon, F.; Petrova, N.; Nurullin, L.; et al. New evidence for dual binding site inhibitors of acetylcholinesterase as improved drugs for treatment of Alzheimer's disease. Neuropharmacology 2019, 155, 131-141. [CrossRef]

58. Mesulam, M.M.; Geula, C. Butyrylcholinesterase reactivity differentiates the amyloid plaques of aging from those of dementia. Ann. Neurol. 1994, 36, 722-727. [CrossRef] [PubMed]

59. Darvesh, S.; Cash, M.K.; Reid, G.A.; Martin, E.; Mitnitski, A.; Geula, C. Butyrylcholinesterase is associated with beta-amyloid plaques in the transgenic APPSWE/PSEN1dE9 mouse model of Alzheimer disease. J. Neuropathol. Exp. Neurol. 2012, 71, 2-14. [CrossRef]

60. Reid, G.A.; Darvesh, S. Butyrylcholinesterase-knockout reduces brain deposition of fibrillar beta-amyloid in an Alzheimer mouse model. Neuroscience 2015, 298, 424-435. [CrossRef] [PubMed] 
61. Darvesh, S.; Reid, G.A. Reduced fibrillar beta-amyloid in subcortical structures in a butyrylcholinesterase-knockout Alzheimer disease mouse model. Chem. Biol. Interact. 2016, 259, 307-312. [CrossRef]

62. Makhaeva, G.F.; Radchenko, E.V.; Palyulin, V.A.; Rudakova, E.V.; Aksinenko, A.Y.; Sokolov, V.B.; Zefirov, N.S.; Richardson, R.J. Organophosphorus compound esterase profiles as predictors of therapeutic and toxic effects. Chem. Biol. Interact. 2013, 203, 231-237. [CrossRef] [PubMed]

63. Makhaeva, G.F.; Lushchekina, S.V.; Kovaleva, N.V.; Yu Astakhova, T.; Boltneva, N.P.; Rudakova, E.V.; Serebryakova, O.G.; Proshin, A.N.; Serkov, I.V.; Trofimova, T.P.; et al. Amiridine-piperazine hybrids as cholinesterase inhibitors and potential multitarget agents for Alzheimer's disease treatment. Bioorg. Chem. 2021, 112, 104974. [CrossRef]

64. Copeland, R.A. Evaluation of Enzyme Inhibitors in Drug Discovery: A Guide for Medicinal Chemists and Pharmacologists; Wiley: New York, NY, USA, 2005; p. 384.

65. Carosati, E.; Sciabola, S.; Cruciani, G. Hydrogen bonding interactions of covalently bonded fluorine atoms: From crystallographic data to a new angular function in the GRID force field. J. Med. Chem. 2004, 47, 5114-5125. [CrossRef] [PubMed]

66. Cheung, J.; Rudolph, M.J.; Burshteyn, F.; Cassidy, M.S.; Gary, E.N.; Love, J.; Franklin, M.C.; Height, J.J. Structures of human acetylcholinesterase in complex with pharmacologically important ligands. J. Med. Chem. 2012, 55, 10282-10286. [CrossRef] [PubMed]

67. Semenov, V.E.; Zueva, I.V.; Mukhamedyarov, M.A.; Lushchekina, S.V.; Kharlamova, A.D.; Petukhova, E.O.; Mikhailov, A.S.; Podyachev, S.N.; Saifina, L.F.; Petrov, K.A.; et al. 6-Methyluracil Derivatives as Bifunctional Acetylcholinesterase Inhibitors for the Treatment of Alzheimer's Disease. ChemMedChem 2015, 10, 1863-1874. [CrossRef]

68. Lushchekina, S.V.; Masson, P. Slow-binding inhibitors of acetylcholinesterase of medical interest. Neuropharmacology 2020, 177, 108236. [CrossRef] [PubMed]

69. López-Iglesias, B.; Pérez, C.; Morales-García, J.A.; Alonso-Gil, S.; Pérez-Castillo, A.; Romero, A.; López, M.G.; Villarroya, M.; Conde, S.; Rodríguez-Franco, M.I. New Melatonin-N,N-Dibenzyl(N-methyl)amine Hybrids: Potent Neurogenic Agents with Antioxidant, Cholinergic, and Neuroprotective Properties as Innovative Drugs for Alzheimer's Disease. J. Med. Chem. 2014, 57, 3773-3785. [CrossRef]

70. Rochais, C.; Lecoutey, C.; Gaven, F.; Giannoni, P.; Hamidouche, K.; Hedou, D.; Dubost, E.; Genest, D.; Yahiaoui, S.; Freret, T.; et al. Novel multitarget-directed ligands (MTDLs) with acetylcholinesterase (AChE) inhibitory and serotonergic subtype 4 receptor (5-HT4R) agonist activities as potential agents against Alzheimer's disease: The design of donecopride. J. Med. Chem. 2015, 58, 3172-3187. [CrossRef]

71. Makhaeva, G.F.; Kovaleva, N.V.; Boltneva, N.P.; Lushchekina, S.V.; Astakhova, T.Y.; Rudakova, E.V.; Proshin, A.N.; Serkov, I.V.; Radchenko, E.V.; Palyulin, V.A.; et al. New Hybrids of 4-Amino-2,3-polymethylene-quinoline and p-Tolylsulfonamide as Dual Inhibitors of Acetyl- and Butyrylcholinesterase and Potential Multifunctional Agents for Alzheimer's Disease Treatment. Molecules 2020, 25, 3915. [CrossRef]

72. Ghotbi, G.; Mahdavi, M.; Najafi, Z.; Moghadam, F.H.; Hamzeh-Mivehroud, M.; Davaran, S.; Dastmalchi, S. Design, synthesis, biological evaluation, and docking study of novel dual-acting thiazole-pyridiniums inhibiting acetylcholinesterase and $\beta$-amyloid aggregation for Alzheimer's disease. Bioorg. Chem. 2020, 103, 104186. [CrossRef]

73. Sánchez Montero, J.M.; Agis-Torres, A.; Solano, D.; Söllhuber, M.; Fernandez, M.; Villaro, W.; Gómez-Cañas, M.; García-Arencibia, M.; Fernández-Ruiz, J.; Egea, J.; et al. Analogues of cannabinoids as multitarget drugs in the treatment of Alzheimer's disease. Eur. J. Pharmacol. 2021, 895, 173875. [CrossRef]

74. Makhaeva, G.F.; Kovaleva, N.V.; Boltneva, N.P.; Lushchekina, S.V.; Rudakova, E.V.; Stupina, T.S.; Terentiev, A.A.; Serkov, I.V.; Proshin, A.N.; Radchenko, E.V.; et al. Conjugates of tacrine and 1,2,4-thiadiazole derivatives as new potential multifunctional agents for Alzheimer's disease treatment: Synthesis, quantum-chemical characterization, molecular docking, and biological evaluation. Bioorg. Chem. 2020, 94, 103387. [CrossRef] [PubMed]

75. Shevtsova, E.F.; Maltsev, A.V.; Vinogradova, D.V.; Shevtsov, P.N.; Bachurin, S.O. Mitochondria as a promising target for developing novel agents for treating Alzheimer's disease. Med. Res. Rev. 2021, 41, 803-827. [CrossRef]

76. Shevtzova, E.F.; Kireeva, E.G.; Bachurin, S.O. Effect of beta-amyloid peptide fragment 25-35 on nonselective permeability of mitochondria. Bull. Exp. Biol. Med. 2001, 132, 1173-1176. [CrossRef]

77. Bachurin, S.O.; Vinogradova, D.V.; Shevtsova, E.F.; Goreva, T.V.; Epishina, T.A.; Aksinenko, A.Y.; Sokolov, V.B. Modification of gamma-carbolines with N-substituted propionamides as a new approach to mitoprotective agents. Russ. Chem. Bull. 2014, 62, 816-819. [CrossRef]

78. Shevtsova, E.F.; Vinogradova, D.V.; Neganova, M.E.; Shevtsov, P.N.; Lednev, B.V.; Bachurin, S.O. Mitochondria are an Important Target in the Search for new Drugs for the Treatment of Alzheimer's Disease and Senile Dementia. Biomed. Chem. Res. Meth. 2018, 1, e00058. [CrossRef]

79. Boyman, L.; Coleman, A.K.; Zhao, G.; Wescott, A.P.; Joca, H.C.; Greiser, B.M.; Karbowski, M.; Ward, C.W.; Lederer, W.J. Dynamics of the mitochondrial permeability transition pore: Transient and permanent opening events. Arch. Biochem. Biophys. 2019, 666, 31-39. [CrossRef]

80. Varidaki, A.; Hong, Y.; Coffey, E.T. Repositioning Microtubule Stabilizing Drugs for Brain Disorders. Front. Cell Neurosci. 2018, 12, 226. [CrossRef]

81. Cattanach, C.J.; Cohen, A.; Heath-Brown, B. Studies in the indole series. IV. Tetrahydro-1H-pyrido[4,3-b]-indoles as serotonin antagonists. J. Chem Soc. Perkin 1 1968, 10, 1235-1243. [CrossRef] 
82. Toscan, C.E.; Rahimi, M.; Bhadbhade, M.; Pickford, R.; McAlpine, S.R.; Lock, R.B. Thioimidazoline based compounds reverse glucocorticoid resistance in human acute lymphoblastic leukemia xenografts. Org. Biomol. Chem. 2015, 13, 6299-6312. [CrossRef]

83. Zhou, L.-M.; Gu, Z.-Q.; Costa, A.M.; Yamada, K.A.; Mansson, P.E.; Giordano, T.; Skolnick, P.; Jones, K.A. (2S, 4R)-4-methylglutamic acid (SYM 2081): A selective, high-affinity ligand for kainate receptors. J. Pharmacol. Exp. Ther. 1997, 280, 422-427.

84. Dana, C.; Benavides, J.; Schoemaker, H.; Scatton, B. Pharmacological characterisation and autoradiographic distribution of polyamine-sensitive [3H]ifenprodil binding sites in the rat brain. Neurosci. Lett. 1991, 125, 45-48. [CrossRef]

85. Coughenour, L.L.; Barr, B.M. Use of trifluoroperazine isolates a [(3)H]Ifenprodil binding site in rat brain membranes with the pharmacology of the voltage-independent ifenprodil site on N-methyl-D-aspartate receptors containing NR2B subunits. J. Pharmacol. Exp. Ther. 2001, 296, 150-159.

86. Nowak, G.; Trullas, R.; Layer, R.T.; Skolnick, P.; Paul, I.A. Adaptive changes in the N-methyl-D-aspartate receptor complex after chronic treatment with imipramine and 1-aminocyclopropanecarboxylic acid. J. Pharmacol. Exp. Ther. 1993, 265, $1380-1386$. [PubMed]

87. Bachurin, S.; Tkachenko, S.; Baskin, I.; Lermontova, N.; Mukhina, T.; Petrova, L.; Ustinov, A.; Proshin, A.; Grigoriev, V.; Lukoyanov, N.; et al. Neuroprotective and cognition-enhancing properties of MK-801 flexible analogs. Structure-activity relationships. Ann. N. Y. Acad. Sci. 2001, 939, 219-236. [CrossRef] [PubMed]

88. Newton, P.; Harrison, P.; Clulow, S. A novel method for determination of the affinity of protein: Protein interactions in homogeneous assays. J. Biomol. Screen. 2008, 13, 674-682. [CrossRef] [PubMed]

89. Ellman, G.L.; Courtney, K.D.; Andres, V., Jr.; Feather-Stone, R.M. A new and rapid colorimetric determination of acetylcholinesterase activity. Biochem. Pharmacol. 1961, 7, 88-95. [CrossRef]

90. Sterri, S.H.; Johnsen, B.A.; Fonnum, F. A radiochemical assay method for carboxylesterase, and comparison of enzyme activity towards the substrates methyl [1-14C] butyrate and 4-nitrophenyl butyrate. Biochem. Pharmacol. 1985, 34, 2779-2785. [CrossRef]

91. Bachurin, S.O.; Shevtzova, E.P.; Lermontova, N.N.; Serkova, T.P.; Ramsay, R.R. The effect of dithiocarbamates on neurotoxic action of 1-methyl-4-phenyl-1,2,3,6 tetrahydropyridine (MPTP) and on mitochondrial respiration chain. Neurotoxicology 1996, 17, 897-903.

92. Åkerman, K.E.O.; Wikström, M.K.F. Safranine as a probe of the mitochondrial membrane potential. FEBS Lett. 1976, 68, 191-197. [CrossRef]

93. Niks, M.; Otto, M. Towards an Optimized Mtt Assay. J. Immunol. Methods 1990, 130, 149-151. [CrossRef]

94. Shelanski, M.L.; Gaskin, F.; Cantor, C.R. Microtubule assembly in the absence of added nucleotides. Proc. Natl. Acad. Sci. USA 1973, 70, 765-768. [CrossRef]

95. Schmidt, M.W.; Baldridge, K.K.; Boatz, J.A.; Elbert, S.T.; Gordon, M.S.; Jensen, J.H.; Koseki, S.; Matsunaga, N.; Nguyen, K.A.; Su, S.; et al. General atomic and molecular electronic structure system. J. Comput. Chem. 1993, 14, 1347-1363. [CrossRef]

96. Nicolet, Y.; Lockridge, O.; Masson, P.; Fontecilla-Camps, J.C.; Nachon, F. Crystal structure of human butyrylcholinesterase and of its complexes with substrate and products. J. Biol. Chem. 2003, 278, 41141-41147. [CrossRef] [PubMed]

97. Masson, P.; Lushchekina, S.; Schopfer, L.M.; Lockridge, O. Effects of viscosity and osmotic stress on the reaction of human butyrylcholinesterase with cresyl saligenin phosphate, a toxicant related to aerotoxic syndrome: Kinetic and molecular dynamics studies. Biochem. J. 2013, 454, 387-399. [CrossRef] [PubMed]

98. Morris, G.M.; Goodsell, D.S.; Halliday, R.S.; Huey, R.; Hart, W.E.; Belew, R.K.; Olson, A.J. Automated docking using a Lamarckian genetic algorithm and an empirical binding free energy function. J. Comput. Chem. 1998, 19, 1639-1662. [CrossRef]

99. Morris, G.M.; Huey, R.; Lindstrom, W.; Sanner, M.F.; Belew, R.K.; Goodsell, D.S.; Olson, A.J. AutoDock4 and AutoDockTools4: Automated docking with selective receptor flexibility. J. Comput. Chem. 2009, 30, 2785-2791. [CrossRef]

100. Voevodin, V.; Antonov, A.; Nikitenko, D.; Shvets, P.; Sobolev, S.; Sidorov, I.; Stefanov, K.; Voevodin, V.; Zhumatiy, S. Supercomputer Lomonosov-2: Large Scale, Deep Monitoring and Fine Analytics for the User Community. Supercomput. Front. Innov. 2019, 6. [CrossRef] 